\title{
Climatology of Mesoscale Warm and Cold Fronts in the Kanto Plain
}

\author{
by \\ Fumiaki Fujibe \\ Meteorological Research Institute, Tsukuba, Ibaraki, 305 Japan
}

(Received October 9, 1991 ; Revised January 16, 1992)

\begin{abstract}
A statistical analysis is made of mesoscale warm fronts (MWFs) and mesoscale cold fronts (MCFs) in the Kanto plain by using hourly surface data covering eleven years. A series of objective criteria are used to select $190 \mathrm{MWFs}$ and $177 \mathrm{MCFs}$, and composite analyses are made of their local structure, seasonal and diurnal variabilities, and the largerscale environment.

MWFs are associated with southeast-southwest winds or northwest winds blowing against a shallow cold-air pool having a depth of a few hundred meters. The MWF associated with southeast-southwest winds corresponds to the warm-air intrusion during the passage of a cyclone, while the MWF associated with northwest winds corresponds to a strong northwesterly surge. The frequency of MWFs is highest between 06 and 12 JST.

The MCF generally occurs during a cold-air surge. From late autumn to winter, the $\mathrm{MCF}$ is mainly associated with northwest winds accompanied by shallow cold air in its leading edge, and is more frequent in the nighttime than in the daytime. From spring to summer, MCFs associated with northeast or east winds are more frequent than those associated with northwest winds, and have a strong tendency to occur in the afternoon.
\end{abstract}

\section{Introduction}

In this article we define the mesoscale front $(\mathrm{MF})$ as a transition zone of wind and temperature having a width of a few tens of kilometers or less. The semi-geostrophic theory (e.g. Hoskins and Bretherton, 1972) predicts that a synoptic-scale front can be contracted into a MF as documented in a number of observational studies (Ogura and Portis, 1982 ; Shapiro, 1984 ; Bond and Fleagle, 1985). However, many MFs in a region of complex terrain may reflect the effect of topography also. A locally intensified front has

(C) 1992 by the Meteorological Research Institute been found to form due to differential surface heating across a coastline (Bosart, 1975; Nielsen, 1989; Nielsen and Neilley, 1990 ; Physick, 1988; Garratt et al., 1989) and/or dynamical effects of orography (Colquhoun et al., 1985; Hoinka et al., 1990; Hartjenstein and Egger, 1990). As a result the climatology of MFs is expected to show regional characteristics according to the topographic environment.

The Kanto plain is bounded by the Pacific Ocean on the east and south and by the Central Mountains on the northwest (Fig. 1). A large number of publications have been issued on the local wind systems in this region. Under weak gradient winds and fair weather, the surface wind fields are characterized by diurnal varia- 

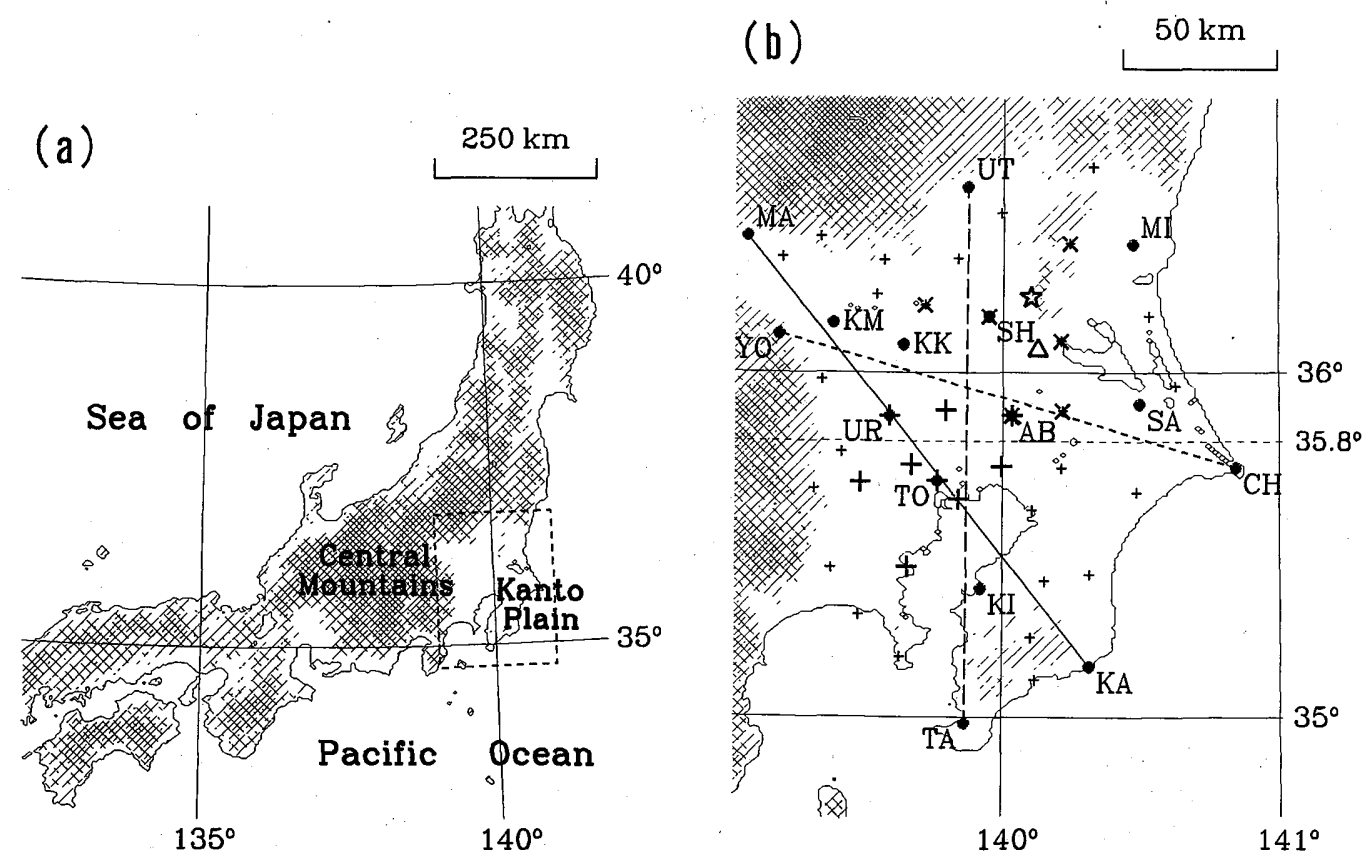

Fig. 1 (a) Topography of central Honshu. Areas above $150 \mathrm{~m}, 300 \mathrm{~m}, 600 \mathrm{~m}$ and $1200 \mathrm{~m}$ are hatched with increasing tones. (b) Topography of the region bounded by dotted lines in (a). The stations used for the analysis of Figs. 4 and 15 are shown in large "+" symbols, and those used for the analysis of Fig. 6 are shown in " $X$ " symbols. The stations presented in the time sections in Figs. 5 and 16 are shown with dots. Other AMeDAS stations used for our analysis are shown with small "+" symbols. The site of the Meteorological Research Institute and the Aerological Observatory of Tateno is denoted by " $\triangle$ ". Mt. Tsukuba is denoted by “饧”.

tion related to the thermal high and low over the Central Mountains (Kimura, 1985; Kondo, 1990) and the land/sea breeze in coastal regions (Fujibe and Asai, 1984; Nakane and Sasano, 1986). Under strong pressure gradient, surface winds exhibit complicated patterns (Kawamura, 1977) associated with a number of convergence lines (Yoshino, 1975; Nomoto, 1975). However, wind fields in the presence of synoptic-scale disturbances have remained much less investigated except for a number of studies on cold fronts (Sugiura, 1974; Sakakibara, 1983; Yamamoto, 1984 ; Fujibe, 1991) and coastal fronts (Fujibe, 1990a, b).

In this article we aim at documenting the collective features of MFs in the Kanto plain by using the hourly data from the AMeDAS (Automated Meteorological Data Acquisition System) netwerk. In view of the limitation in the resolution and reliability of the data, we restrict our analysis to intense, traveling MFs detected from an abrupt change in wind and temperature. Such MFs are naturally classified into warm and cold fronts. Hereafter we call them "mesoscale warm fronts (MWFs)" and "mesoscale cold fronts (MCFs)", respectively. We make composite analyses in search of their local structure, seasonal and diurnal variabilities, and relationship to the larger-scale fields.

\section{Data and procedure of analysis}

\subsection{Data}

The AMeDAS network covers the Kanto plain with resolution of $\sim 20 \mathrm{~km}$ (Fig. 1b). Hourly data of wind direction, wind speed, temperature, duration of sunshine and precipitation are recorded at units of 16 points of the compass, $1 \mathrm{~ms}^{-1}, 0.1^{\circ} \mathrm{C}, 0.1$ hour and $1 \mathrm{~mm}$, respectively. Our analysis is made for the 
period 1979-1989. Temperature is adjusted to the sea level with a lapse rate of $5^{\circ} \mathrm{Ckm}^{-1}$.

At the meteorological tower of the Meteorological Research Institute (MRI ; $\triangle$ in Fig. 1b, 24.5m above the mean sea level), wind and temperature are observed at levels of 10 , $25,50,100,150,200$ and $213 \mathrm{~m}$ above the ground. Hourly data are available on a data file for 1979 -1986 .

At the Aerological Observatory of Tateno, which is close to the MRI, upper-level sounding is made every six hours for wind and twice daily for temperature and humidity.

\subsection{Selection of MWFs and MCFs}

Detection of MFs is made by using a simple algorithm which seeks for a line of wind and temperature change associated with inflow from outside the plain. The condition of inflow in defined on the basis of the wind data at four stations on the periphery of the plain (Choshi, Tateyama, Maebashi and Mito; $\mathrm{CH}, \mathrm{TA}, \mathrm{MA}$ and MI in Fig. 1b) in the following manner:

(a) The wind direction at Choshi is between ENE and SW with wind speed of $5 \mathrm{~ms}^{-1}$ or more (in this article the range of wind direction is indicated clockwise, so that "between ENE and SW" means the range from ENE through SE to SW).

(b) The wind direction at Tateyama is between $\mathrm{E}$ and WSW with wind speed of $5 \mathrm{~ms}^{-1}$ or more.

(c) The wind direction at Maebashi is between WSW and NNE with wind speed of $3 \mathrm{~ms}^{-1}$ or more.

(d) The wind direction at Mito is between $\mathrm{NNW}$ and ESE with wind speed of $3 \mathrm{~ms}^{-1}$ or more.

For the period in which any one of (a)-(d) is satisfied, time changes of temperature and wind are examined for 47 stations in the main part of the plain with altitudes below $150 \mathrm{~m}$ (shown by dots or "+" and " $x$ " symbols in Fig. 1b). For temperature, the departure from the average for the 47 stations is used in order to eliminate the effect of diurnal temperature variation. A frontal passage at a station requires that the following conditions be satisfied :

(e) The departure temperature changes by at least $1.5^{\circ} \mathrm{C}$ in an hour.

(f) Either the wind direction changes by at least $90^{\circ}$, or the wind speed increases by at least $3 \mathrm{~ms}^{-1}$ in the same hour.

(g) The wind direction just after the change is within $45^{\circ}$ of that at any one of the upwind stations which satisfy (a)-(d).

(h) From subjective judgment, the changes (e) -(g) can be recognized as a frontal passage.

If frontal passage is detected at eight stations or more, and can be traced as a propagating line, then the case is selected as representing a MF. A MF associated with temperature rise is defined as a MWF and one associated with temperature drop is defined as a MCF.

This algorithm includes rather severe requirements satisfied by intense MFs only, so that it excludes weak MFs which are difficult to distinguish without a higher degree of subjectivity.

\section{Results}

\subsection{MWFs}

\section{(a) Classification}

The number of MWFs selected for our analysis is 190 . Fig. 2 shows the histogram of the postfrontal wind direction, which is obtained by vector-averaging the winds just after the frontal passage at stations where the front passage is detected. Each graph is stratified with the six-hour precipitation averaged for these stations with the front passage time as the center of the six-hour period. MWFs are separated into two groups with wind directions $90^{\circ}-240^{\circ}$ and $270^{\circ}-360^{\circ}$. We separate the former group into $\mathrm{W}_{\mathrm{SE}}$ and $\mathrm{W}_{\mathrm{SW}}$ fronts corresponding to wind directions $90^{\circ}-180^{\circ}$ and $180^{\circ}-240^{\circ}$, respectively. The front associated with winds from $270^{\circ}-360^{\circ}$ is named the $\mathrm{W}_{\mathrm{NW}}$ front. The numbers of $\mathrm{W}_{\mathrm{SE}}, \mathrm{W}_{\mathrm{SW}}$ and $\mathrm{W}_{\mathrm{NW}}$ fronts are 20 , 114 and 56, respectively.

The classification based on the wind direction alone may not reflect the variable 


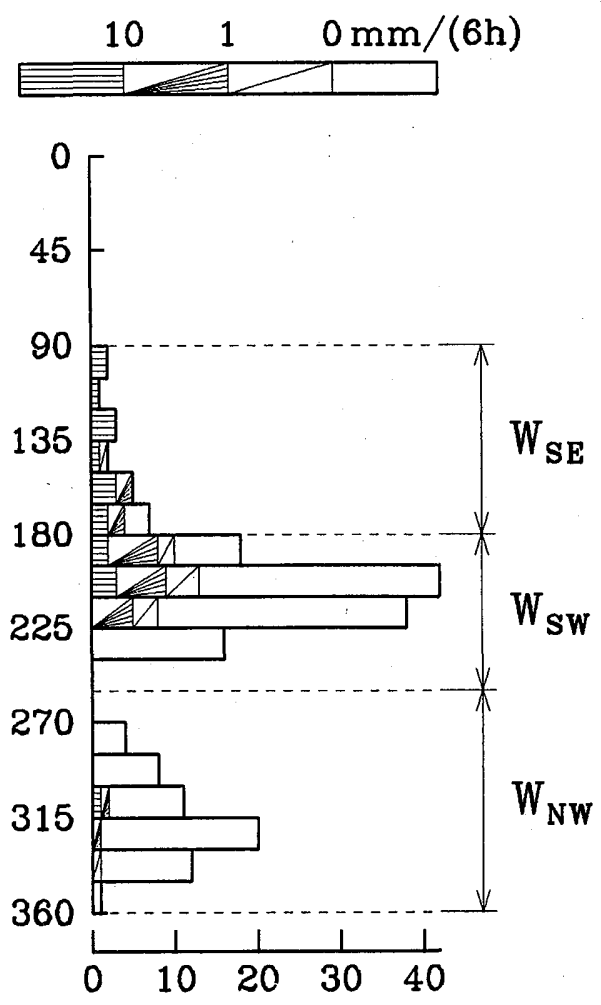

Fig. 2 Histogram of the postfrontal wind direction (degrees) for MWFs stratified according to the six-hour precipitation amount.

features of MFs. However, more detailed classification calls for more subjective judgment. It is not our purpose to enter into such details at the cost of objectivity, but rather to pick up the representative features common to many cases.

Fig. 3 shows the relation between the postfrontal wind direction and the prefrontal wind direction, namely the wind direction just before the frontal passage. The $\mathrm{W}_{\mathrm{SE}}$ front tends to be associated with north or northeast wind, while the $\mathrm{W}_{\text {sw }}$ front can be associated with winds from any direction. The $\mathrm{W}_{\mathrm{Nw}}$ front is typically associated with west or northwest winds, so that its passage results in increase of wind speed with little change in wind direction (as shown later in Figs. 5 and 26).

Table 1 shows the duration of each type of front. More than half of the fronts vanish

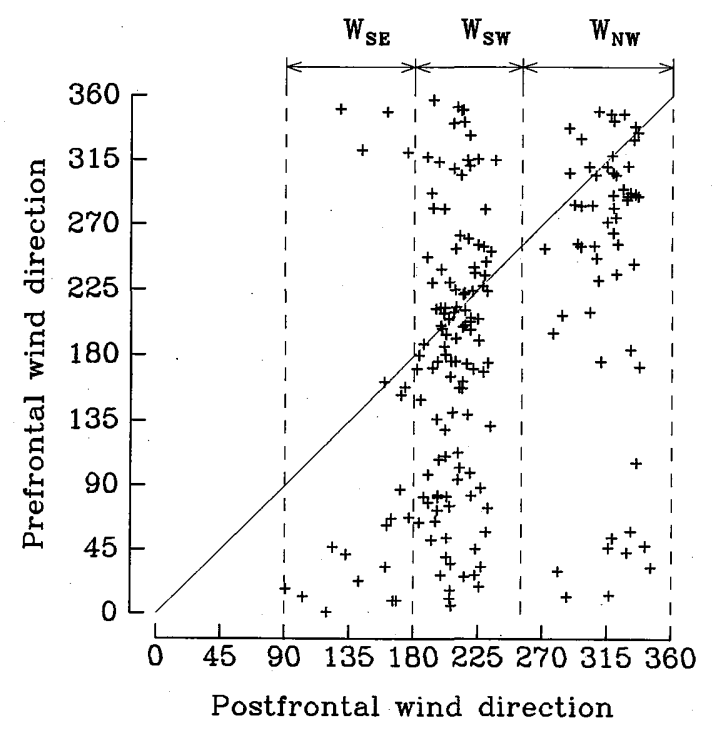

Fig. 3 Relation of the postfrontal wind direction and the prefrontal wind direction for MWFs.

Table 1 Duration of each type of MWF : number of cases for each duration range and mean duration.

\begin{tabular}{|c|c|c|c|c|c|c|c|}
\hline Type & Total & $\leqq 6$ & $7-9$ & $10-12$ & $13-18$ & $\begin{array}{c}<18 \\
\text { (hours) }\end{array}$ & Mean \\
\hline & & & & \multicolumn{3}{|c|}{ (number of fronts) } & (hours) \\
\hline $\mathrm{W}_{\mathrm{SE}}$ & 20 & 5 & 6 & 5 & 3 & 1 & 10.3 \\
\hline $\mathrm{W}_{\mathrm{sw}}$ & 114 & 30 & 41 & 24 & 16 & 3 & 9.3 \\
\hline $\mathrm{W}_{\mathrm{NW}}$ & 56 & 23 & 22 & 7 & 4 & 0 & 7.5 \\
\hline
\end{tabular}

within 9 hours, but some of the $\mathrm{W}_{\mathrm{SE}} / \mathrm{W}_{\mathrm{sw}}$ fronts last more than 12 hours. These long-lasting fronts move very slowly against the cold air in the inland region.

\section{(b) Local structure}

Fig. 4 shows the composite surface field for the three types of MWF. Each composite field shows the surface field just after the front passage at Tokyo (TO in Fig. 1b). Fig. 5 shows the time-distance section along one of the three lines (YO-CH, MA-KA and UT-TA) shown in Fig. 1b. These composite analyses are made for the cases in which the front passage is detected at any one of the nine stations in the vicinity of Tokyo (denoted by large "+" symbols in Fig. 


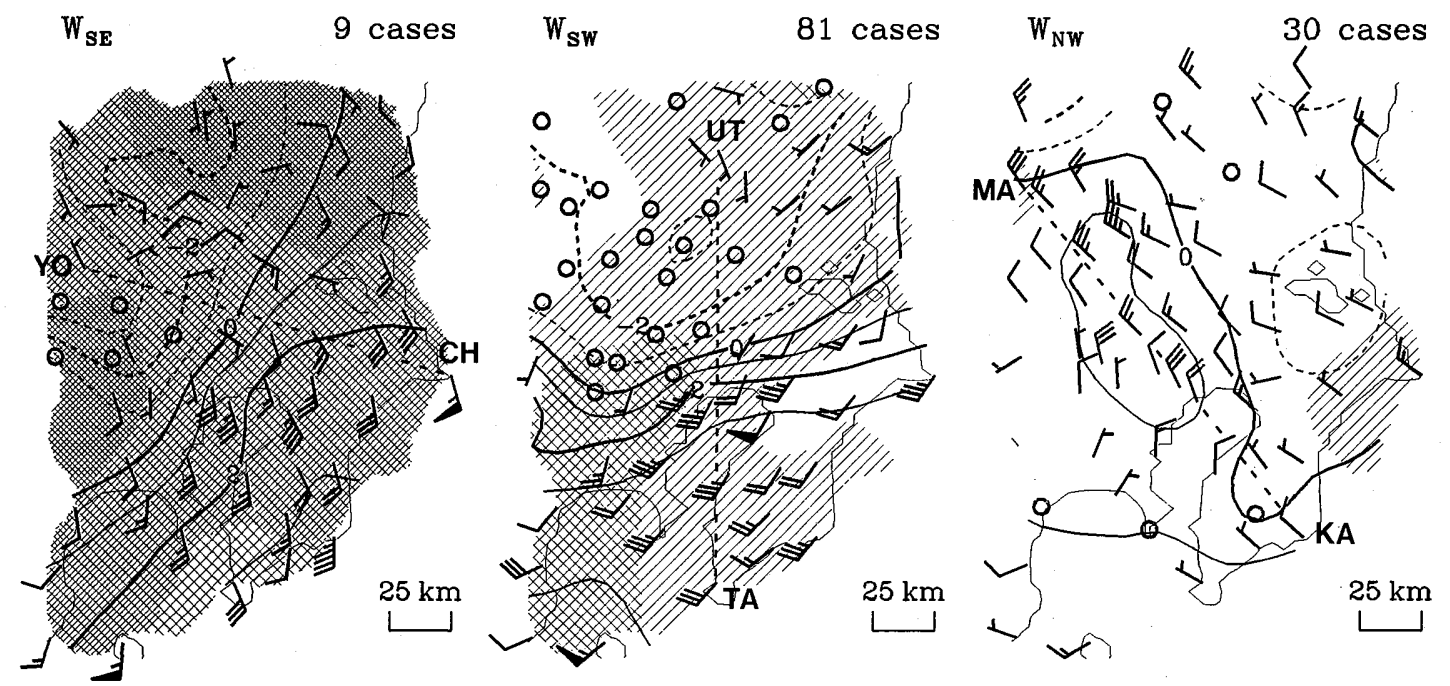

Fig. 4 Composite field of wind, temperature and precipitation intensity for MWFs just after the front passage at Tokyo. Full barbs indicate $2 \mathrm{~ms}^{-1}$ and pennants $10 \mathrm{~ms}^{-1}$, and circles indicate calm $\left(<0.5 \mathrm{~ms}^{-1}\right)$. Temperature is shown by subtracting the spatial average, and isotherms are drawn with $1^{\circ} \mathrm{C}$ intervals with dashed lines for negative values. The regions with precipitation intensity greater than 9.1, 0.25, 1 and 4 $\mathrm{mmh}^{-1}$ are hatched with increasing tones.
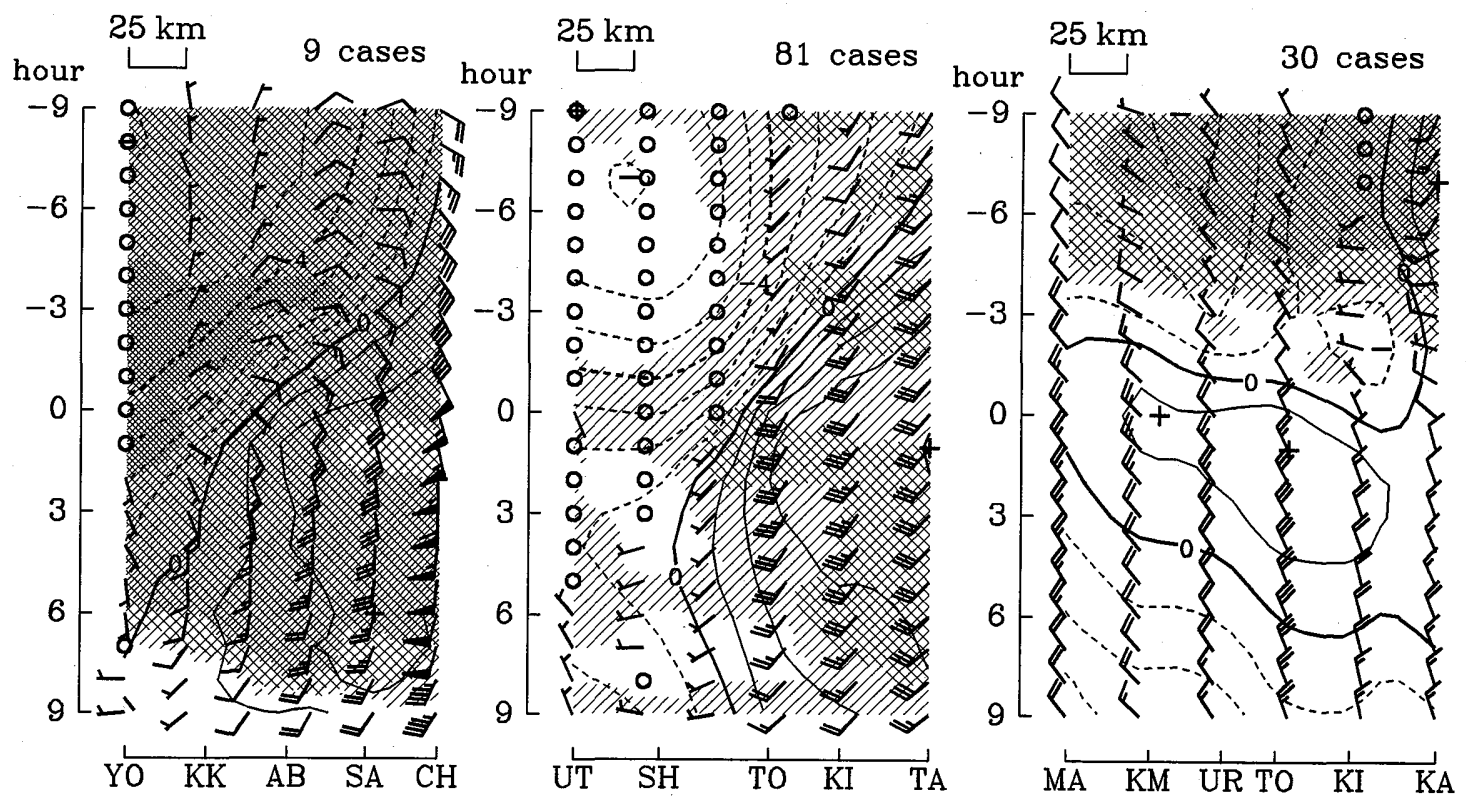

Fig. 5 Composite time section of wind, temperature and precipitation intensity along the lines shown in Fig. 4 (see Fig. 1b for the location of intermediate stations). The time of reference ( 0 hour) is the time of front passage at Tokyo. Symbols are the same as used in Fig. 4. Temperature is shown by subtracting the spatial average at the time of reference. 
1b). The front passage time at Tokyo is obtained by fitting the front passage time at stations where a front passage is detected by using the least-square method.

The $\mathrm{W}_{\mathrm{SE}}$ front forms in the northeast -southwest direction associated with southeast winds blowing from the Pacific, and moves toward the northwest. Precipitation of $1 \mathrm{~mm} /$ (6h) or more is observed except for four cases. There is a slight indication of heavier precipitation in the inland region than in the coastal region.

The $\mathrm{W}_{\mathrm{sw}}$ front lies in the east-west direction with southwest winds on its south. The calm state on its north is the result of averaging many cases with variable wind directions (Fig. $3)$. Precipitation is much less frequent than in the case of the $\mathrm{W}_{\mathrm{SE}}$ front $(\geqq 1 \mathrm{~mm} /(6 \mathrm{~h})$ in 22 out of 114 cases). In fact, the frequency of precipitation decreases as the postfrontal wind direction turns from east to southwest as seen from Fig. 2.

The $\mathrm{W}_{\mathrm{Nw}}$ front is accompanied by northwest winds blowing from the northwestern part of the plain. The structure of the front is not clearly seen in Figs. 4 and 5 ; in fact this type of front is usually most conspicuous in the northwestern part of the plain and tends to become less obvious as it moves southeast (e.g. Fig. $26 \mathrm{~b})$. Precipitation is rare during the passage of the front $(\geqq 1 \mathrm{~mm} /(6 \mathrm{~h})$ in 3 out of 56 cases).

Fig. 6 shows the vertical time section at the MRI tower and the AMeDAS station of Mt.
Tsukuba (s in Fig. 1b, $868 \mathrm{~m}$ above the mean sea level) for the period 1979-1986. This analysis is made for the cases in which the front passage is detected at any one of the six surrounding stations denoted by " $X$ " in Fig. 1b. Before the front passage, there is a cold-air pool below the height of a few hundred meters, above which the wind direction agrees with the postfrontal wind direction. After the front passage, the cold-air pool disappears and the wind direction becomes nearly uniform throughout the boundary layer.

In the following analysis (Figs. 7-12 except Fig. 9) we represent the front passage time by the average for the stations where a front passage is detected. Fig. 7 shows the relation of the postfrontal wind direction and the $850 \mathrm{hPa}$ wind direction at Tateno stratified according to the $850 \mathrm{hPa}$ wind speed. Among six-hourly data of the $850 \mathrm{hPa}$ wind, those at the observation time nearest the front passage time are shown. The postfrontal wind direction roughly agrees with the $850 \mathrm{hPa}$ wind direction with wind speed exceeding $10 \mathrm{~ms}^{-1}$ in most cases. These facts indicate that the MWF is the boundary of a deep layer of strong wind and a shallow cold-air pool.

\section{(c) Seasonal and diurnal variations}

Fig. 8 shows the season-time of the day diagram for each type of MWF. Stratification with precipitation amount is made in the same way as in Fig. 2. The $\mathrm{W}_{\mathrm{SE}}$ front is observed
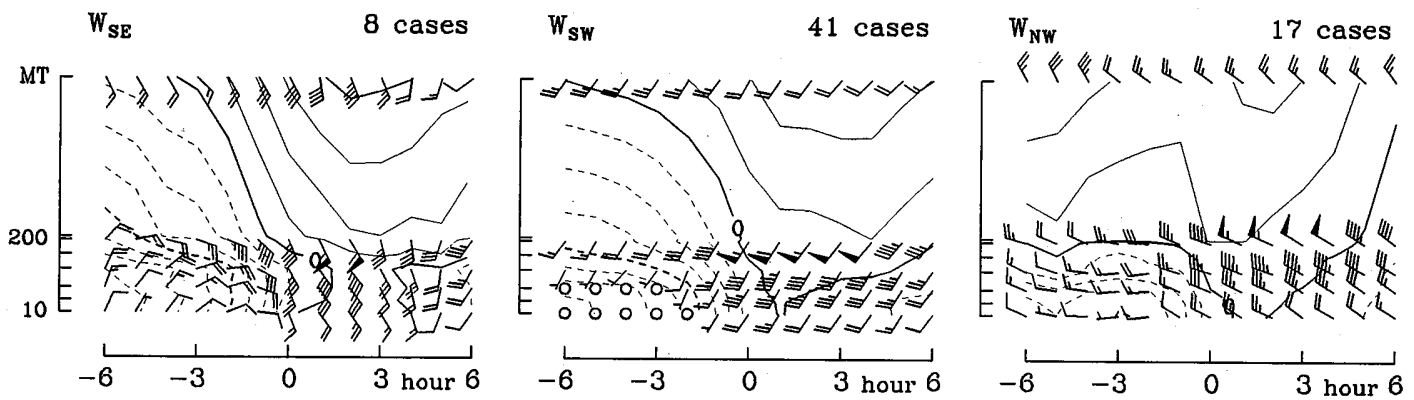

Fig. 6 Composite vertical time section of wind and potential temperature $\left(T+\Gamma_{d} Z ; \Gamma_{d}\right.$ is the dry adiabatic lapse rate) at the MRI tower and Mt. Tsukuba (MT). The time of reference is the front passage time at the MRI. Symbols are the same as those used in Fig. 4. Potential temperature is shown by subtracting the spatial average temperature at surface at the time of reference. 
mainly in spring and autumn. The $\mathrm{W}_{\mathrm{SE}}$ fronts in spring accompany extratropical cyclones, while six out of the seven cases between June and October accompany tropical cyclones. The $\mathrm{W}_{\text {sw }}$ front can be observed in any season, but is more frequent from late autumn to early spring

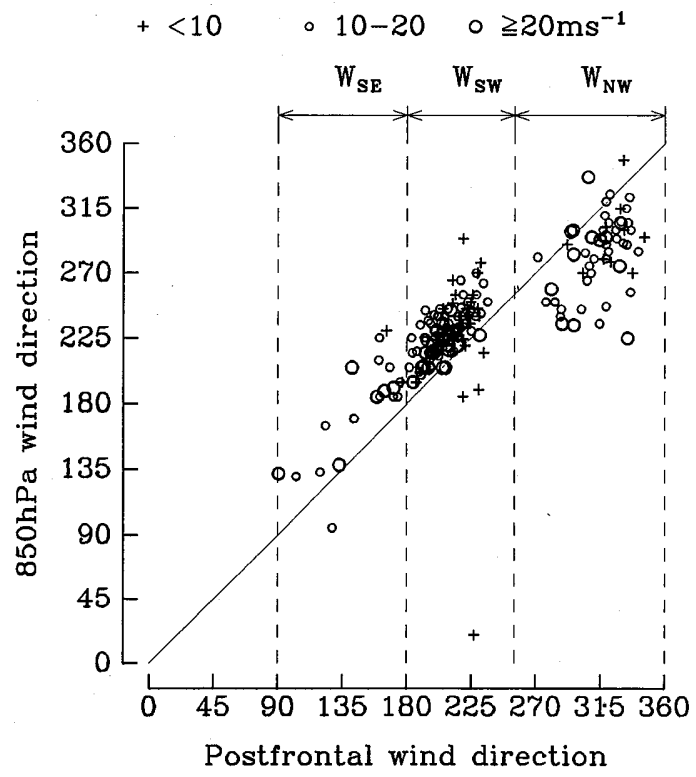

Fig. 7 Relation between the postfrontal wind direction and the $850 \mathrm{hPa}$ wind direction at Tateno stratified according to the $850 \mathrm{hPa}$ wind speed.
(91 out of 114 cases are observed during the six months November-April). The $\mathrm{W}_{\mathrm{Nw}}$ front is most frequent in cold seasons (37 out of 56 cases are observed during the four months December -March).

The mean location of the $\mathrm{W}_{\mathrm{sw}}$ front varies according to seasons. Fig. 9 shows the composite time section for the $\mathrm{W}_{\mathrm{sw}}$ front for October - January and April-August. For OctoberJanuary, the front moves from the south coast to the central part of the plain with the northern region dominated by cold air. For April-August, the southern part of the plain is dominated by southwest winds from the beginning, and the front moves northward from the central part of the plain. However, there appears to be no essential difference in the vertical structure of the front (not shown).

We can also observe in Fig. 8 that the frequency of the $\mathrm{W}_{\mathrm{Sw}}$ and the $\mathrm{W}_{\mathrm{NW}}$ fronts has a distinct maximum between 06 and 12 JST (65 out of $114 \mathrm{~W}_{\mathrm{SW}}$ cases and 23 out of $56 \mathrm{~W}_{\mathrm{NW}}$ cases), although the small number of $\mathrm{W}_{\mathrm{sw}}$ cases with substantial precipitation $(\geqq 1 \mathrm{~mm} /(6 \mathrm{~h}))$ show little diurnal variation. The four $\mathrm{W}_{\mathrm{SE}}$ fronts with precipitation less than $1 \mathrm{~mm} /(6 \mathrm{~h})$ are also clustered in this time of the day. Thus the MWF is generally most frequently observed between 06 and 12 JST if precipitation is weak or absent.

$$
\begin{array}{lll}
035.2-35.8^{\circ} \mathrm{N} & \Delta 35.8-36.4^{\circ} \mathrm{N} \\
\circ \text { None } \quad \text { ( <1 } & \bullet 1-10 \quad \bullet \geqq 10 \mathrm{~mm} /(6 \mathrm{~h})
\end{array}
$$
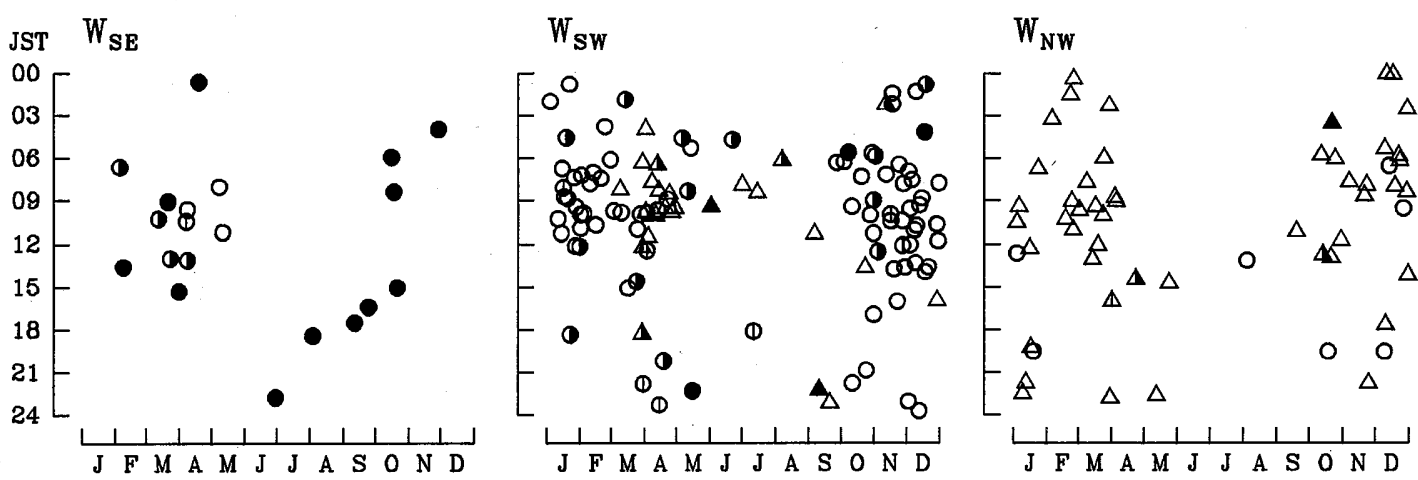

Fig. 8 Scatter diagram for the seasonal and diurnal distribution of MWFs. Data are stratified with six-hour precipitation amount, and also with the mean latitude of the front for the $\mathrm{W}_{\mathrm{sw}}$ and $\mathrm{W}_{\mathrm{NW}}$ fronts. 

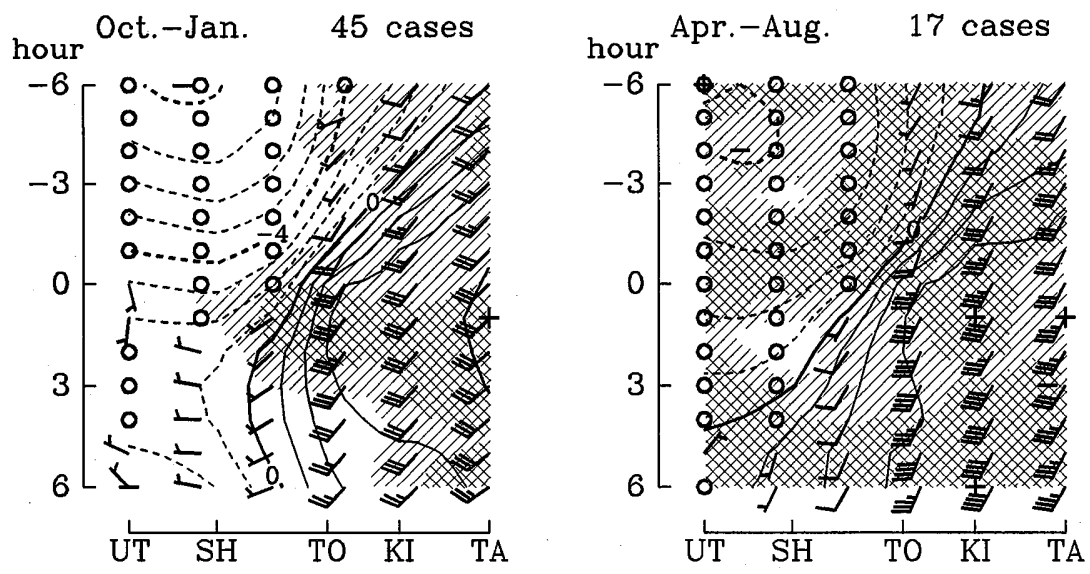

Fig. 9 Same as Fig. 5 but for the $\mathrm{W}_{\mathrm{sw}}$ front in October-January and April -August.

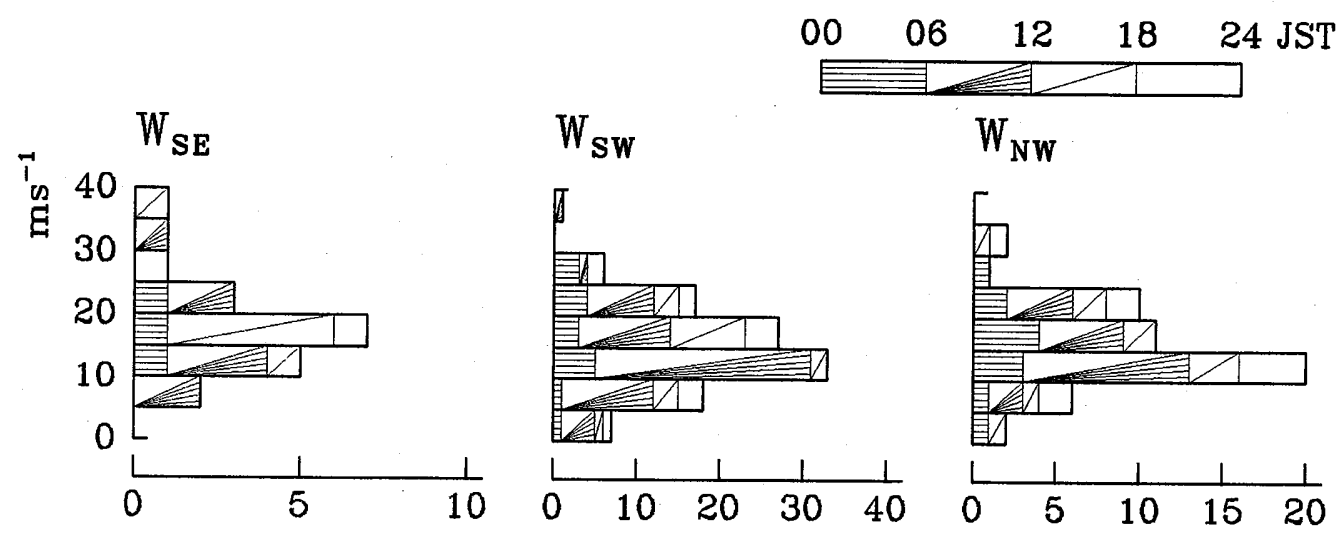

Fig. 10 Histograms of the $850 \mathrm{hPa}$ wind speed for each type of MWF stratified according to the front passage time.

Fig. 10 shows the histogram of the $850 \mathrm{hPa}$ wind speed stratified according to the front passage time. Ranks of lower wind speed include $06-12$ JST cases at a higher percentage. For example, out of $48 \mathrm{~W}_{\mathrm{sw}}$ fronts which occur when the $850 \mathrm{hPa}$ wind is weaker than $15 \mathrm{~ms}^{-1}$, 41 cases occur during $06-12$ JST. This indicates that the threshold wind speed for the occurrence of the MWF is lower in late morning than in other time of the day.

\section{(d) Larger-scale fields and parameters}

Fig. 11 shows the composite pressure field based on six-hourly data of sea-level pressure at observatories of the Japan Meteorological
Agency (JMA). Data at the observation time nearest the front passage time are used in constructing the composite field. The $\mathrm{W}_{\mathrm{SE}}$ front occurs to the east of a cyclone embedded in a north-south oriented trough over western Honshu. The $\mathrm{W}_{\mathrm{sw}}$ front occurs to the south of a low, which is typically located over the Sea of Japan (e.g. Fig. 26). In both cases, the cold air in the inland Kanto plain is isolated in the field of widespread warming which is shown by hatching. In the case of the $\mathrm{W}_{\mathrm{SE}}$ front the region of cold air corresponds to a pressure ridge extending southwestward from a high located to the east of Honshu, while in the case of the $\mathrm{W}_{\mathrm{sw}}$ front a pressure ridge extends 
northeastward from a high located to the south of Honshu. Since the pressure excess in the northwestern part of the Kanto plain is $\sim 0.5$ $\mathrm{hPa}$ and the inland-coast temperature difference is a few degrees, the depth of the cold air can be estimated to be several hundred meters, in rough agreement with the result in Fig. 6.

The $\mathrm{W}_{\mathrm{NW}}$ front corresponds to a strong northwesterly wind surge accompanied by widespread cooling. The warm frontal character is therefore a local feature in the field of cold-air advection. In fact, the surface temperature over the Kanto plain begins to drop a few hours after the passage of the $\mathrm{W}_{\mathrm{NW}}$ front (Fig. 5).

Fig. 12 shows the time series of several parameters at surface and the $850 \mathrm{hPa}$ level. The average front passage time is used as the time of reference ( 0 hour). The surface temperature and precipitation amount are obtained by averaging the data at 47 stations in the Kanto plain. The cloud amount is obtained from the three-hourly observation data at Tokyo. The $850 \mathrm{hPa}$ temperature and equivalent potential temperature $\left(\theta_{e}\right)$ are obtained from the halfdaily sounding at Tateno. These are used after

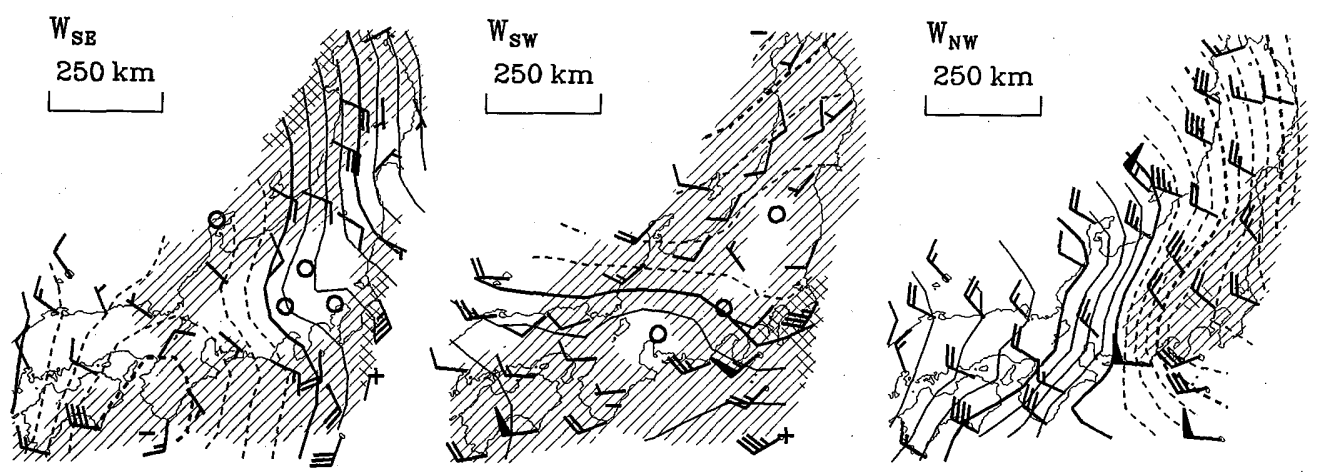

Fig. 11 Composite field of sea-level pressure and surface wind. Wind is shown in the same manner as in Fig. 4. Pressure is shown by subtracting the spatial average for the region, and isobars are drawn at $1 \mathrm{hPa}$ intervals with dashed lines for negative values. The regions in which temperature has risen by $1^{\circ} \mathrm{C}$ and $3^{\circ} \mathrm{C}$ during the previous 24 hours are hatched with increasing tones.

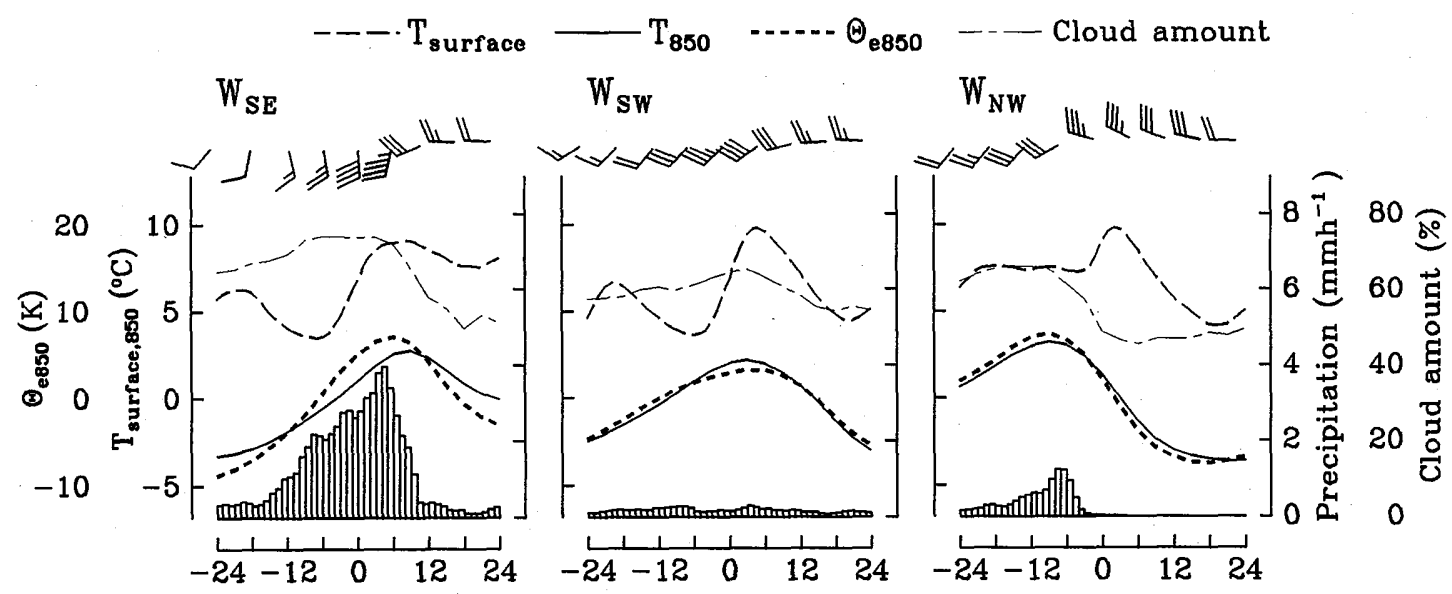

Fig. 12 Composite time series of surface and $850 \mathrm{hPa}$ parameters for MWFs. Arrows indicate the $850 \mathrm{hPa}$ wind with full barbs for $5 \mathrm{~ms}^{-1}$. Temperature $\left(T_{\text {surface }}\right.$ and $\left.T_{850}\right)$ and equivalent potential temperature $\left(\theta_{\mathrm{e} 850}\right)$ are shown by subtracting the 48 -hour averages at the $850 \mathrm{hPa}$ level. 
interpolating hourly values by using the cubic spline functions of Akima (1970). The $\mathrm{W}_{\mathrm{SE}}$ front is associated with strong south winds and warming at the $850 \mathrm{hPa}$ level, where temperature becomes highest about 9 hours after the occurrence of the front. The $\mathrm{W}_{\mathrm{sw}}$ front occurs in the later stage of warm-air intrusion associated with southwest winds at the $850 \mathrm{hPa}$ level. On the other hand, the $\mathrm{W}_{\mathrm{NW}}$ front occurs simultaneously with the beginning of the temperature drop and the onset of the northwest wind at the $850 \mathrm{hPa}$ level. The opposite temperature change between surface and the $850 \mathrm{hPa}$ level confirms that the warm frontal character results from the transition of the boundary-layer structure.

\subsection{MCFs}

(a) Classification

The number of MCFs is 177 . Fig. 13 shows the distribution of the postfrontal wind directions. MCFs correspond to wind directions between $255^{\circ}$ and $135^{\circ}$ except for three cases. We define $\mathrm{C}_{\mathrm{NW}}, \mathrm{C}_{\mathrm{NE}}$ and $\mathrm{C}_{\mathrm{E}}$ fronts corresponding to wind directions $255^{\circ}-15^{\circ}, 15^{\circ}-75^{\circ}$ and $75^{\circ}-135^{\circ}$ with 97, 53 and 24 cases, respectively. Precipitation of $1 \mathrm{~mm} /(6 \mathrm{~h})$ or more is observed in nearly half of the cases $(39 / 97)$ of the $\mathrm{C}_{\mathrm{NW}}$ front but is less frequent as the wind direction turns toward the east (8/53 for the $\mathrm{C}_{\mathrm{NE}}$ front and $1 / 24$ for the $C_{E}$ front).

Fig. 14 shows the relation between the postfrontal wind direction and the prefrontal wind direction. The $\mathrm{C}_{\mathrm{Nw}}$ front is mostly associated with southwest winds. The $\mathrm{C}_{\mathrm{NE}}$ front also tends to be associated with southwest winds, although there is considerable scatter in the prefrontal wind direction. The $C_{E}$ front tends to be associated with northerly winds.

Table 2 shows the duration of each type of MCF. In comparison to the MWF, the MCF tends to be short-lived. In particular, more than half of the $\mathrm{C}_{\mathrm{NW}}$ fronts (59/97) disappear within 6 hours.

\section{(b) Local structure}

Fig. 15 shows the composite surface field for the three types of MCF at the front passage time at Tokyo. Fig. 16 shows the time-distance
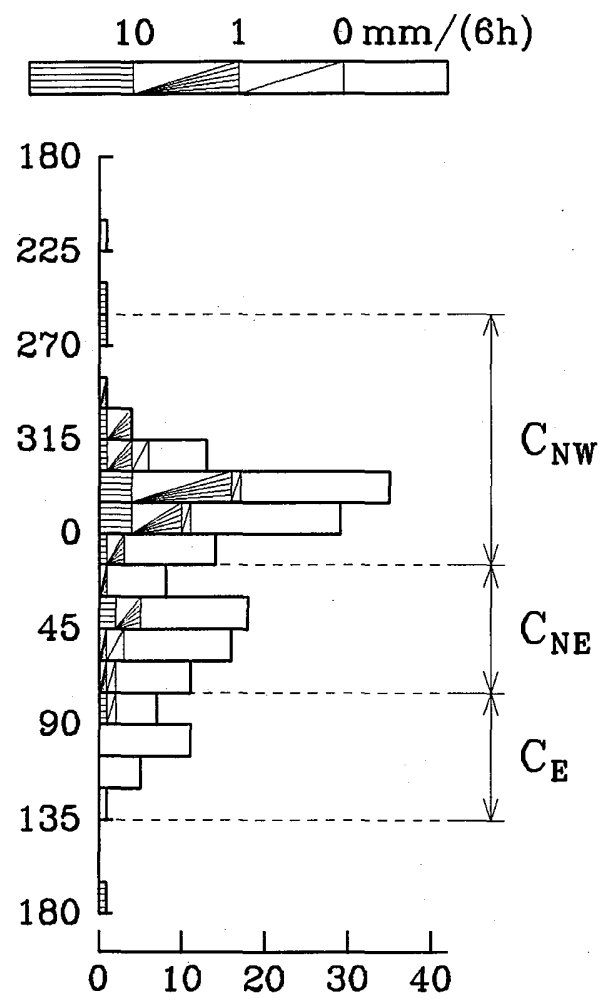

Fig. 13 Same as Fig. 2 but for MCFs.

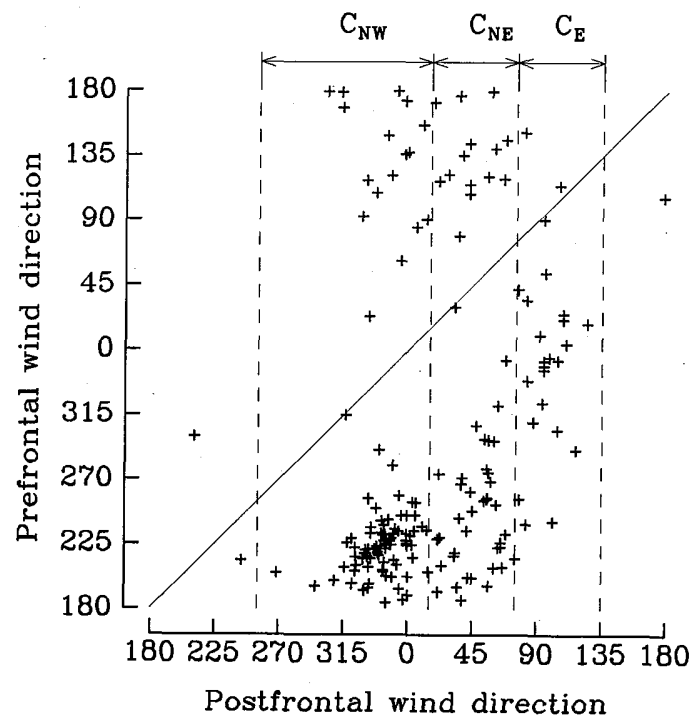

Fig. 14 Same as Fig. 3 but for MCFs. 
Table 2 Same as Table 1 but for the MCF.

\begin{tabular}{lcrrrrcc}
\hline Type & Total & $\leqq 6$ & $7-9$ & $10-12$ & $13-18$ & $\begin{array}{c}<18 \\
\text { (hours) }\end{array}$ \\
\hline & & & \multicolumn{5}{c}{ Mean } \\
$\mathrm{C}_{\mathrm{NW}}$ & 97 & 59 & 27 & 6 & 5 & 0 & 6.5 \\
$\mathrm{C}_{\mathrm{NE}}$ & 53 & 15 & 26 & 10 & 2 & 0 & 7.8 \\
$\mathrm{C}_{\mathrm{E}}$ & 24 & 7 & 14 & 3 & 0 & 0 & 7.3 \\
\hline
\end{tabular}

section along one of the three lines $(\mathrm{CH}-\mathrm{YO}$, KA-MA and TA-UT) shown in Fig. 1b. The $\mathrm{C}_{\mathrm{NW}}$ front is located in the northeast-southwest or east-west direction, while the $\mathrm{C}_{\mathrm{NE}}$ front is located in the east-west or southeast-northwest direction. The $\mathrm{C}_{\mathrm{E}}$ front is directed in the north -south direction and moves westward.
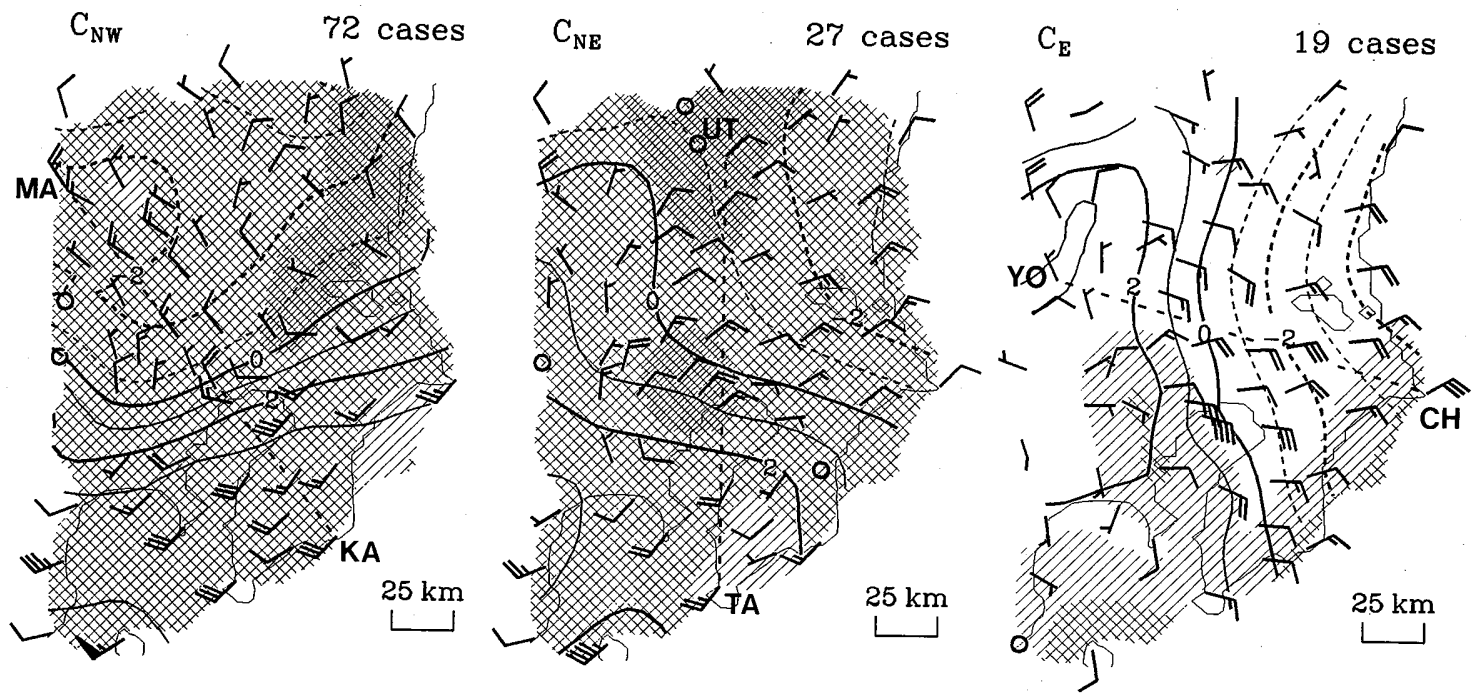

Fig. 15 Same as Fig. 4 but for MCFs.
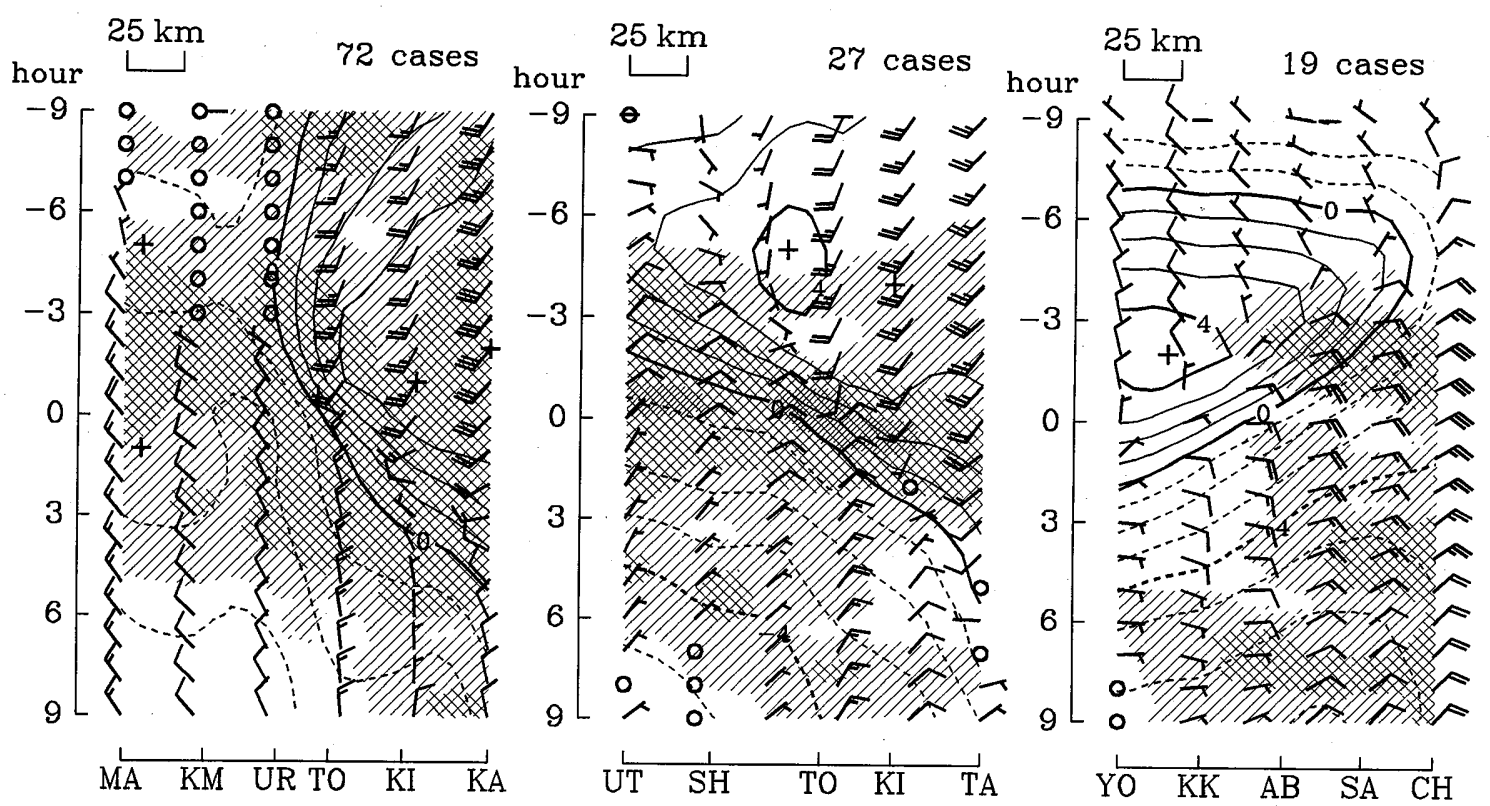

Fig. 16 Same as Fig. 5 but for MCFs. 
In order to evaluate the vertical structure of the front, we compare the postfrontal wind direction and the wind direction at the $850 \mathrm{hPa}$ level at Tateno. Fig. 17 shows their relation stratified according to the $850 \mathrm{hPa}$ wind speed. Considering the possibility of a time lag in the front passage at upper levels, the $850 \mathrm{hPa}$ wind data 12 hours after the surface front passage are shown. For the $\mathrm{C}_{\mathrm{NW}}$ front, the $850 \mathrm{hPa}$ wind direction is mostly from the west or north with wind speeds exceeding $10 \mathrm{~ms}^{-1}$ in nearly half of the cases $(43 / 92)$. For the $C_{N E} / C_{E}$ front, the $850 \mathrm{hPa}$ wind is weaker than $10 \mathrm{~ms}^{-1}$ in most cases (39/52 and $21 / 24$, respectively) and tends to blow from the westerly direction. This indicates that the $\mathrm{C}_{\mathrm{Nw}}$ front tends to be associated with a deep and strong northwesterly surge, while the $\mathrm{C}_{\mathrm{NE}} / \mathrm{C}_{\mathrm{E}}$ front tends to be associated with a shallow northeast-east wind with its top lower than the $850 \mathrm{hPa}$ level.

Fig. 18 shows the vertical sounding at Tateno at $21 \mathrm{JST}$ for six cases in which $\mathrm{C}_{\mathrm{NW}}$ and $C_{E}$ fronts occurred in the afternoon. For $C_{N W}$ fronts, the top of the northwest wind is typically around the $800 \mathrm{hPa}$ level. The northwest wind layer is slightly more stable than the layer

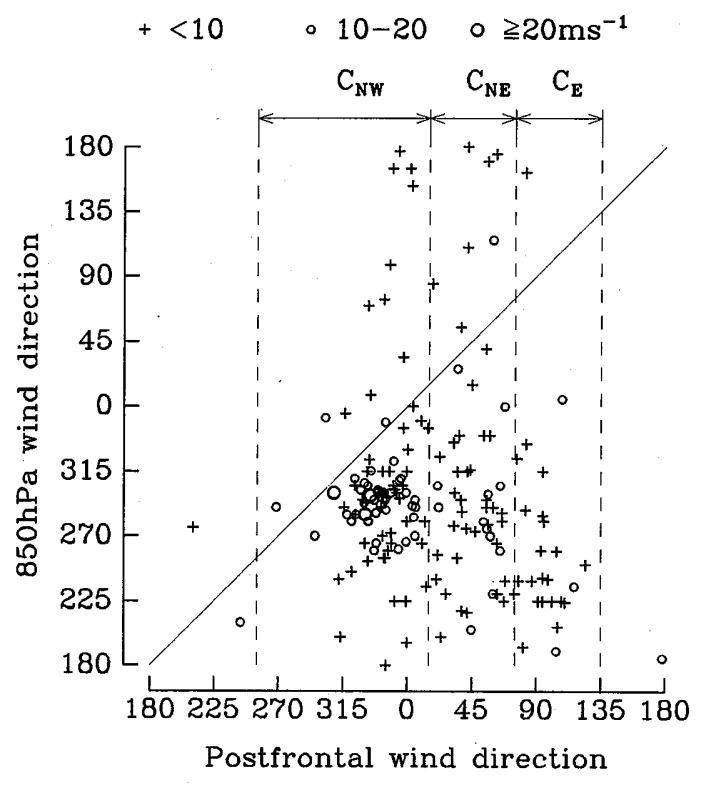

Fig. 17 Relation between the postfrontal wind direction and the $850 \mathrm{hPa}$ wind direction 12 hours after the front passage stratified according to the $850 \mathrm{hPa}$ wind speed.
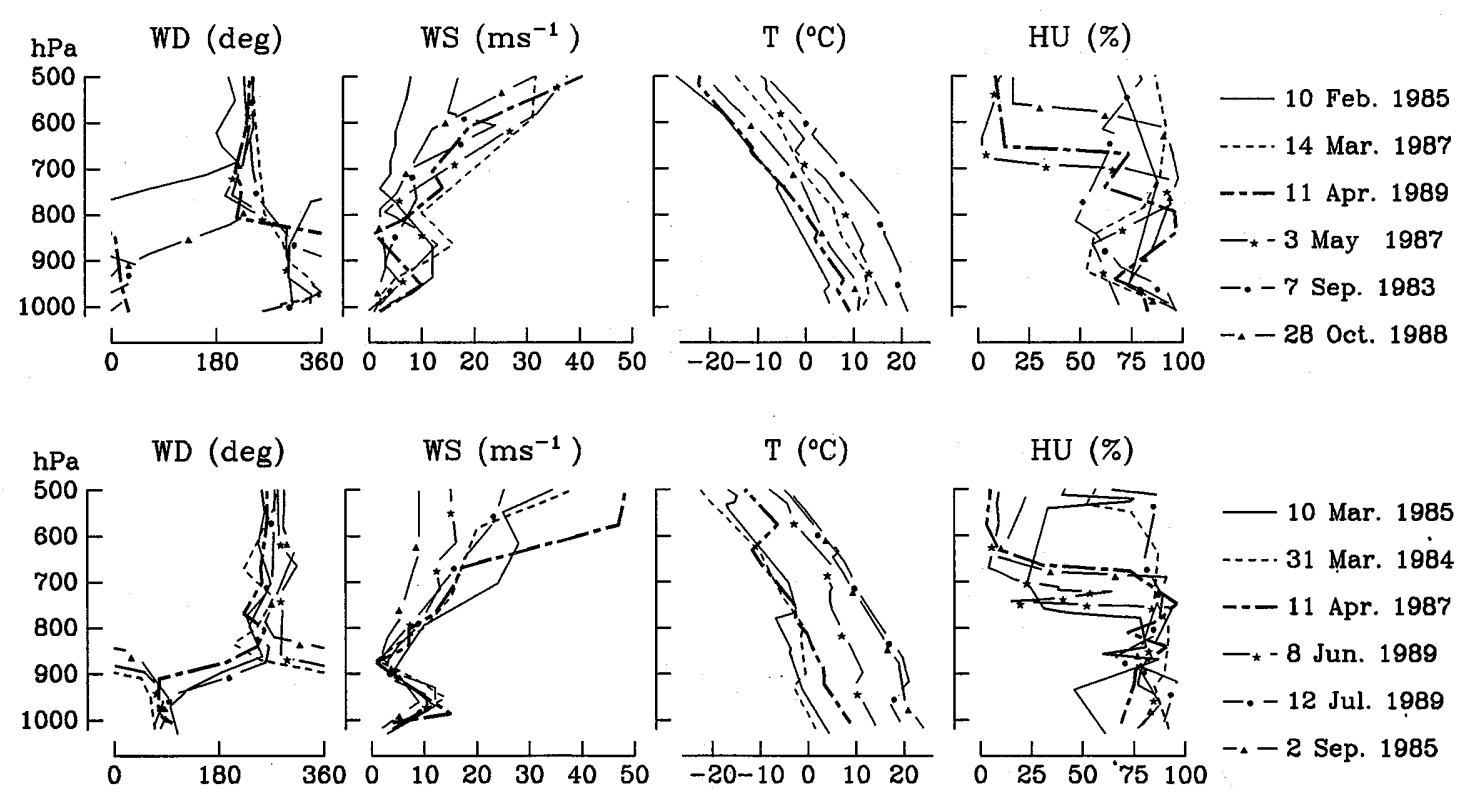

Fig. 18 Vertical sounding at 21 JST for six cases of the $\mathrm{C}_{\mathrm{NW}}$ (upper) and $\mathrm{C}_{\mathrm{E}}$ (lower) fronts. 
above, but the frontal inversion is not obvious. In comparison, the top of the east wind associated with the $\mathrm{C}_{\mathrm{E}}$ front is between the $950 \mathrm{hPa}$ and the $900 \mathrm{hPa}$ level, and is often capped by a well-defined inversion layer. The shallow cold air surmounted by inversion is the general feature of the $\mathrm{C}_{\mathrm{NE}}$ front also (not shown).

\section{(c) Seasonal and diurnal variations}

Fig. 19 shows the season-time of the day diagram of each type of MCF. The $\mathrm{C}_{\mathrm{Nw}}$ front is observed in any season although rare in summer, while the diurnal variability and the position of the front show considerable seasonal differences. Form late autumn to winter, the $\mathrm{C}_{\mathrm{NW}}$ front is more frequent in the nighttime than in the daytime and is mostly observed in the southern part of the plain. In spring and summer, the $\mathrm{C}_{\mathrm{NW}}$ front is most frequent in the afternoon and is mainly observed in the northern plain. For example, out of the 41 cases in the four months October-January, 25 occur in 18-06 JST and 34 occur south of the $35.8^{\circ} \mathrm{N}$ line, while out of the 29 cases in the five months April-August, 20 occur in 12-18 JST and 20 occur north of the $35.8^{\circ} \mathrm{N}$ line.

Fig. 20 shows the composite surface and vertical time sections for the $\mathrm{C}_{\mathrm{NW}}$ front for October-January and April-August. In October -January the $\mathrm{C}_{\mathrm{NW}}$ front typically moves from the central part of the plain to the south coast with the northern part of the plain covered by cold air all the time. The cold air is very shallow $(\sim 200 \mathrm{~m})$ for a few hours after the frontal passage, although it soon becomes deep as observed from the onset of the northwest wind at Mt. Tsukuba. Aside from the direction of the movement, the spatial structure of the leading edge of the front is similar to that of the $\mathrm{W}_{\mathrm{sw}}$ front. Precipitation is relatively infrequent (13 out of 41 cases) and does not well correspond to the position of the front. On the other hand, the $\mathrm{C}_{\mathrm{NW}}$ front in April-August arrives from the northwest corner of the plain accompanied by cold air deeper than Mt. Tsukuba. Precipitation is more frequent (15 out of 29 cases) than in October-January and roughly corresponds to the front.

The $\mathrm{C}_{\mathrm{NE}}$ and $\mathrm{C}_{\mathrm{E}}$ front shows a strong tendency to occur from spring to summer and between 12 and 18 JST. Of the 53 cases of the $\mathrm{C}_{\mathrm{NE}}$ front, 35 occur between 12 and 18 JST. The $\mathrm{C}_{\mathrm{E}}$ front is restricted to the seven months from March to September, and 21 out of 24 cases occur between 12 and 18 JST.

\section{(d) Larger-scale fields and parameters}

Fig. 21 shows the sea-level pressure field around central Honshu. The higher pressure toward the northwest is common to the three types of front. Thus the MCF generally occurs

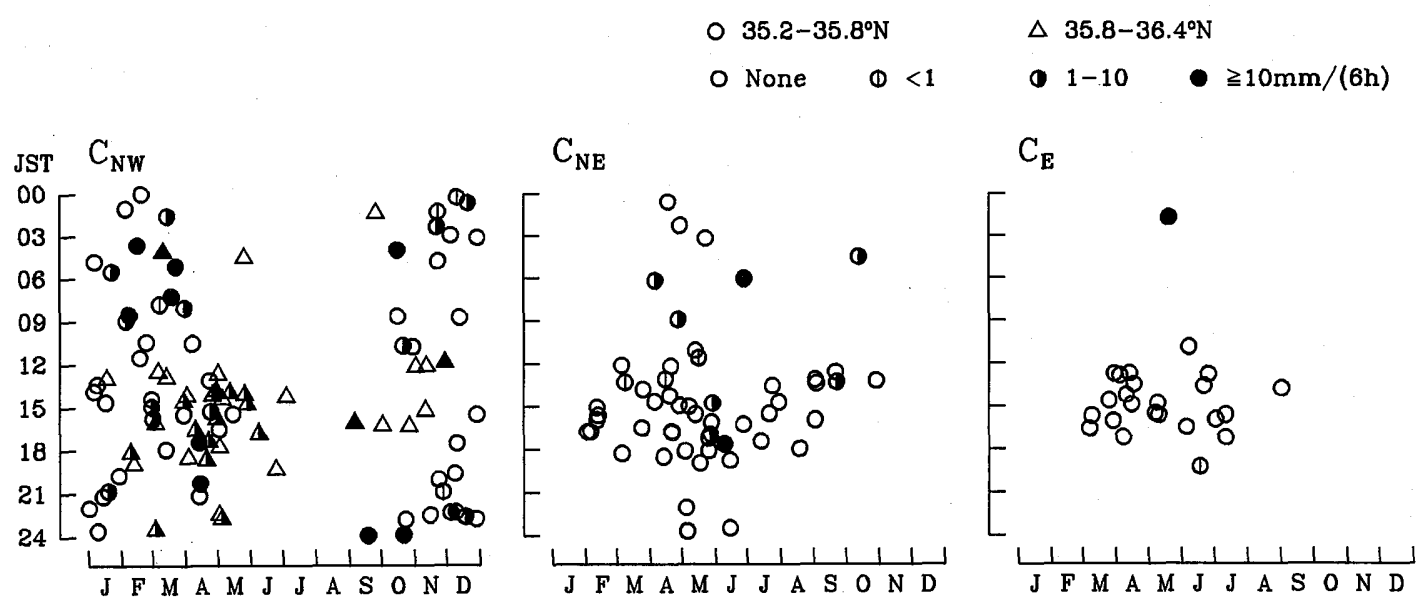

Fig. 19 Same as Fig. 8 but for MCFs. Stratification with latitude is made only for the $\mathrm{C}_{\mathrm{NW}}$ front. 

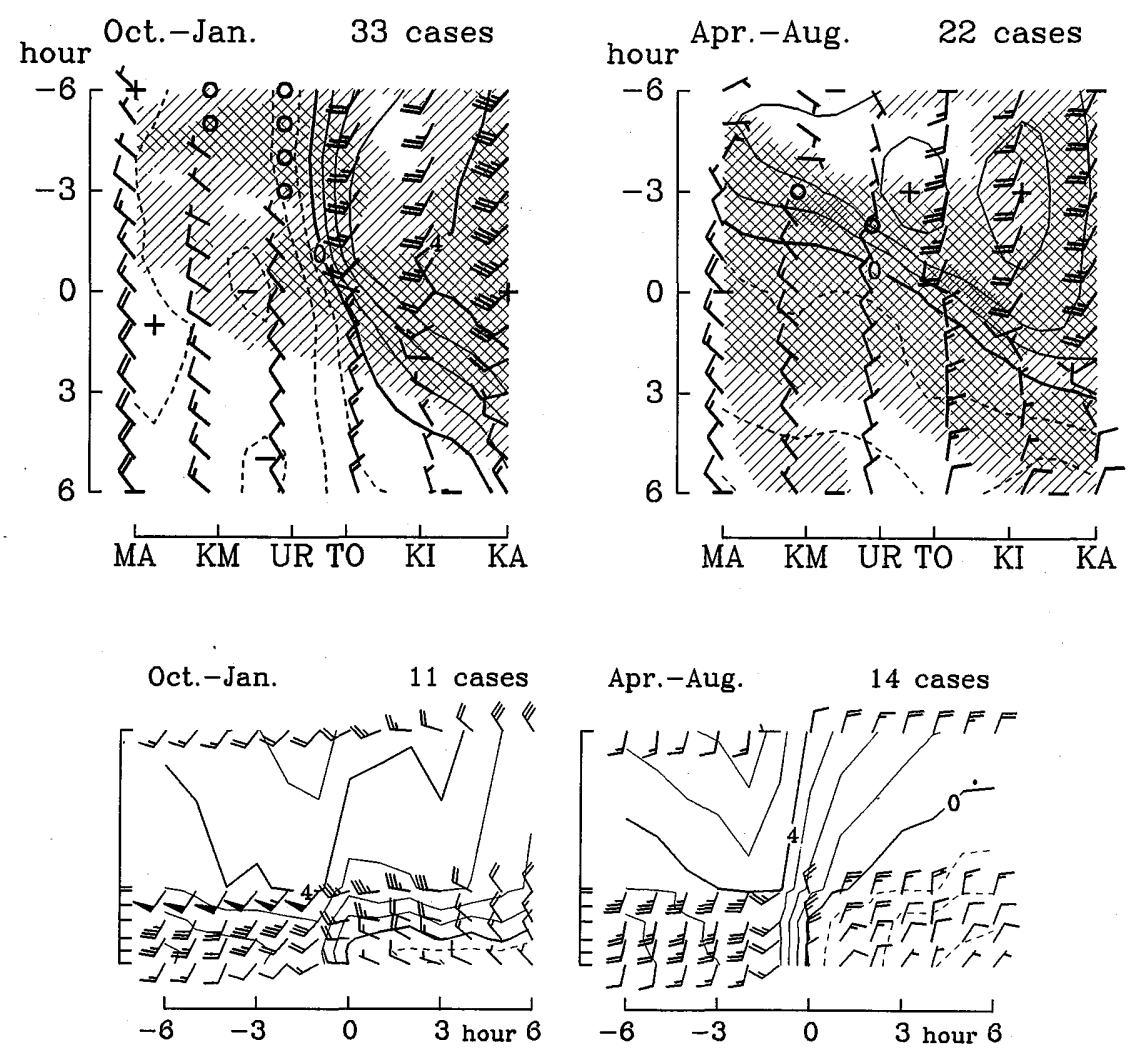

Fig. 20 Same as Figs. 5 and 6 but for the $C_{\mathrm{NW}}$ front in October-January and April-August.
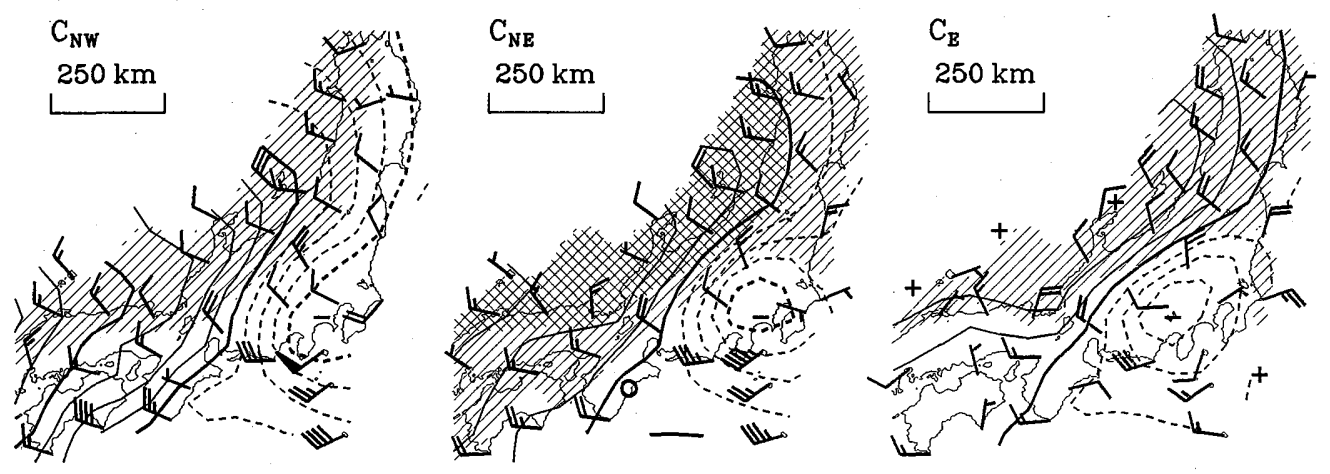

Fig. 21 Same as Fig. 11 but for MCFs. Hatching indicates the area in which temperature has dropped during the preceding 24 hours, with double hatching for a drop of more than $2^{\circ} \mathrm{C}$. 
in the situation of a cold-air surge. The pressure gradient is strongest for the $\mathrm{C}_{\mathrm{Nw}}$ front and weakest for the $C_{E}$ front, although slightly weaker than in the case of the $\mathrm{W}_{\mathrm{NW}}$ front even for the $\mathrm{C}_{\mathrm{NW}}$ front. The direction of the geostrophic wind has a larger easterly component in the case of the $\mathrm{C}_{\mathrm{NE}} / \mathrm{C}_{\mathrm{E}}$ front than for the $\mathrm{C}_{\mathrm{Nw}}$ front, but nevertheless the wind direction in most regions of Honshu is northwest or north. In other words, the easterly wind associated with the $C_{N E} / C_{E}$ front is a local feature corresponding to the mesolow to the west of the plain.

In view of the strong diurnal variation in the frequency of the $\mathrm{C}_{\mathrm{NE}} / \mathrm{C}_{\mathrm{E}}$ front, it is worth examining whether the mesolow is observed irrespective of the time of the day or only in the afternoon. Fig. 22 shows the pressure field at 03 and 15 JST for the $\mathrm{C}_{\mathrm{NE}}$ front which occurred during 00-06 JST and 12-18 JST, respectively. A mesolow exists to the west of the Kanto plain in both cases, and also in other time of the day (06-12 JST and 18-24 JST) not shown here. Therefore diurnal heating is not necessary, although may be favorable, for the formation of the mesolow.

Fig. 23 shows the time series of surface and $850 \mathrm{hPa}$ parameters. The $\mathrm{C}_{\mathrm{NW}}$ front coincides with the beginning of the temperature drop at the $850 \mathrm{hPa}$ level, while the occurrence of the $\mathrm{C}_{\mathrm{NE}}$ and $\mathrm{C}_{\mathrm{E}}$ fronts delays the beginning of the $850 \mathrm{hPa}$ temperature drop by $6-12$ hours and 12 -18 hours, respectively. According to surface weather maps, most $\mathrm{C}_{\mathrm{NW}}$ fronts agree with the
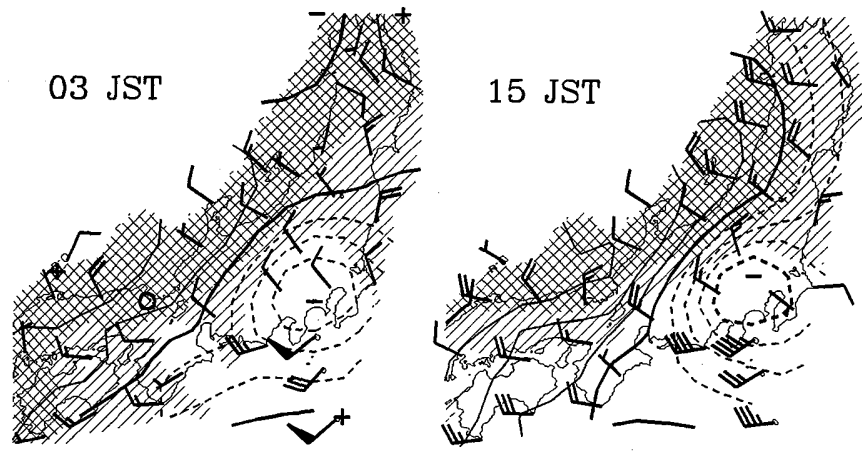

Fig. 22 Sea-level pressure field at 03 and 15 JST for the $C_{N E}$ front which occurred during 00-06 JST and 12-18 JST, respectively.

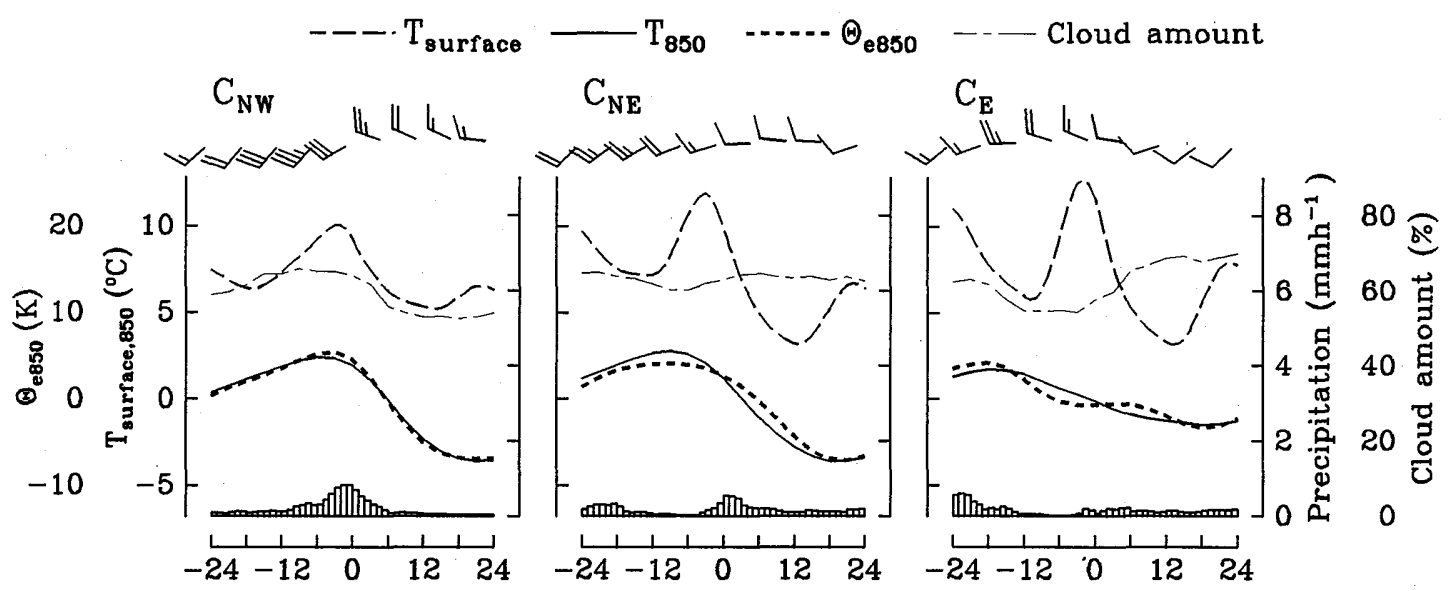

Fig. 23 Same as Fig. 12 but for the MCF. 


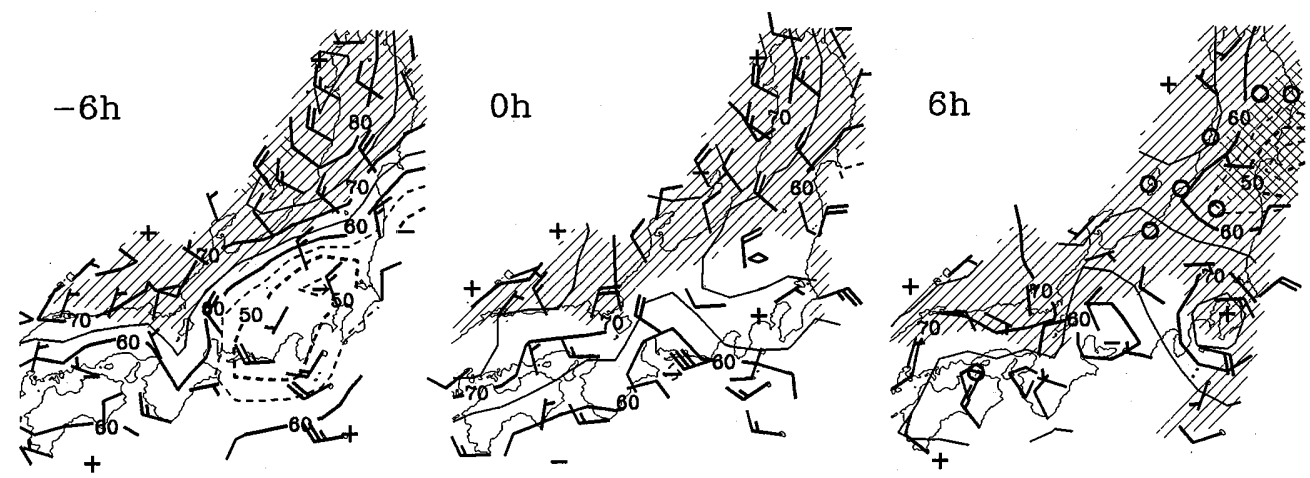

Fig. 24 Composite field of cloud amount (\%) and wind every six hours before and after the occurrence of the $\mathrm{C}_{\mathrm{E}}$ front. Contour intervals are $5 \%$, and dashed lines indicate values less than $60 \%$. The meaning of the hatching is the same as in Fig. 21.

passage of a synoptic-scale cold front or a secondary meso- $\alpha$-scale trough, while most $C_{E}$ fronts occur well north of a synoptic-scale cold front drawn in weather maps. The $\mathrm{C}_{\mathrm{NE}}$ front sometimes corresponds to the passage of a synoptic-scale cold front oriented in the eastwest direction, and sometimes occurs more than a few hours after the cold frontal passage.

The $\mathrm{C}_{\mathrm{Nw}}$ front coincides with the time of maximum precipitation, and is followed by a decrease in cloud amount. In contrast, the $C_{E}$ front tends to occur under fair weather followed by an increase in cloud amount. Fig. 24 shows the distribution of cloud amount every six hours before and after the $C_{E}$ front passage. Before the passage of the front, the Kanto plain is a region of localized low cloudiness $(<50 \%)$ with temperature higher than the climatic normal. On the average for the 23 cases of the $C_{E}$ front (except for a case in the nighttime), the daily maximum temperature at Tokyo is higher than the climatological normal by $2.4^{\circ} \mathrm{C}$. After the passage of the $C_{E}$ front, the Kanto plain becomes a region of high cloudiness $(>70 \%)$ which is sometimes accompanied by weak but continuous precipitation (Fig. 23). This is a type of the "northeasterly cloudy weather" notorious among the forecasters.

The cloudiness after the passage of the $C_{E}$ front corresponds to low stratus over the inversion layer above the easterly wind (Fig. 18). For the six cases shown in Fig. 18, the average low cloud amount $\mathrm{Nh}$ in the weather report) is $6 / 8$, and the cloud base is below $1 \mathrm{~km}$ except for the case on 10 March 1985 . The top of the cloud layer is usually low, as suggested from the low humidity above the $700 \mathrm{hPa}$ level.

Fig. 25 shows an example of the $C_{E}$ front on 11 April 1987. At 09 JST 11 April, the synopticscale cold front had already moved to the east of Honshu, and the Kanto plain was dominated by northwest winds. The $850 \mathrm{hPa}$ temperature at Tateno had dropped by $5^{\circ} \mathrm{C}$ after 21 JST 10 April. However, surface temperatures in the Kanto plain remained high until the arrival of the $C_{E}$ front in the afternoon. This was followed by increase in low clouds and weak rain, which lasted throughout 12 April.

\subsection{Combination of fronts}

More than one MF often occurs in sequence during the passage of a synoptic-scale cyclone. We define "sequential fronts" as those in which the latter front begins within 12 hours of the ending of the former. If two fronts coexist for three hours or more, we call them "simultaneous fronts".

The combination of fronts can be classified into following types, where the symbols " $\rightarrow$ " and "+" indicate sequential and simultaneous fronts, respectively :

(a) Warm southerly $\rightarrow$ cold northerly (39 cases)

$\mathrm{W}_{\mathrm{sw}} \rightarrow \mathrm{C}_{\mathrm{NW}}$ (30 cases)

$\mathrm{W}_{\mathrm{SE}} \rightarrow \mathrm{C}_{\mathrm{NW}}$ (3 cases) 


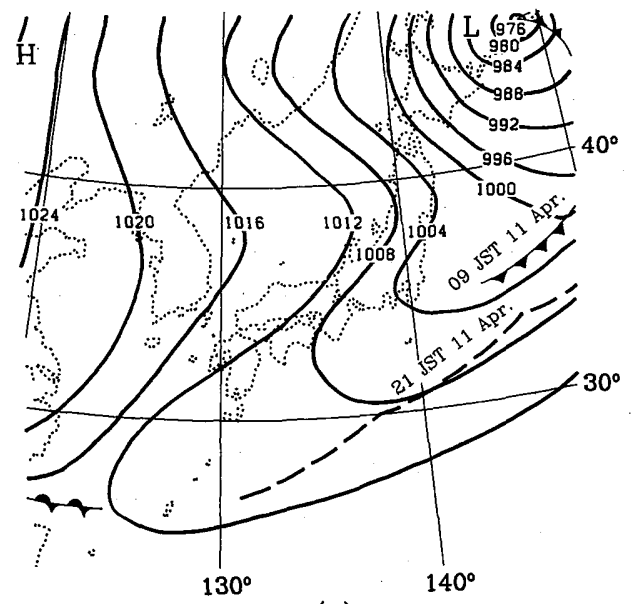

(a)

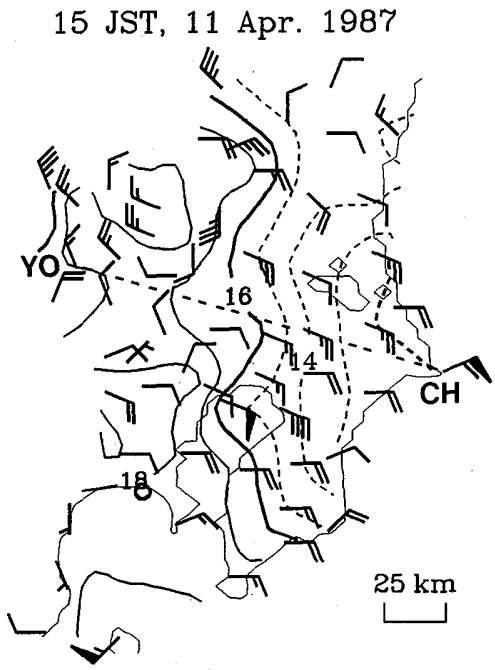

(b)
11-12 Apr. 1987

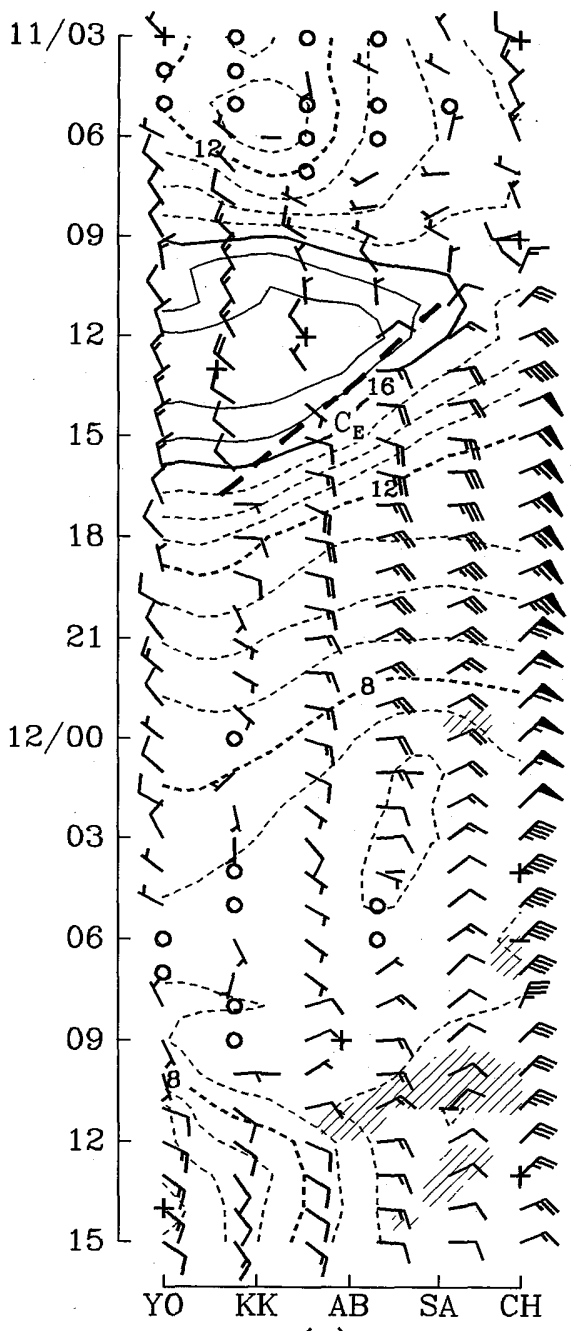

(c)

Fig. 25 (a) Surface pressure map (hPa) at 09 JST 11 April 1987. The position of the synoptic-scale front at 21 JST is shown by a dashed line. (b) Surface wind and temperature $\left({ }^{\circ} \mathrm{C}\right)$ at 15 JST 11 April. (c) Time section of surface wind and temperature $\left({ }^{\circ} \mathrm{C}\right)$ on the $\mathrm{YO}-\mathrm{CH}$ line. Symbols in (b) and (c) are the same as in Fig. 4, but hatching indicates the region with precipitation intensity exceeding $0.25 \mathrm{mmh}^{-1}$.

$\mathrm{W}_{\mathrm{SW}} \rightarrow \mathrm{C}_{\mathrm{NE}}(6$ cases $)$

(b) Warm southerly $\rightarrow$ warm northerly (17 cases)

$\mathrm{W}_{\mathrm{sw}} \rightarrow \mathrm{W}_{\mathrm{NW}}$ (15 cases)

$\mathrm{W}_{\mathrm{SE}} \rightarrow \mathrm{W}_{\mathrm{NW}}$ ( 2 cases)

(c) Warm northerly and cold northerly (17 cases)

$\mathrm{W}_{\mathrm{NW}}+\mathrm{C}_{\mathrm{NW}}$ (11 cases)

$\mathrm{W}_{\mathrm{NW}} \rightarrow \mathrm{C}_{\mathrm{NW}}$ (1 case)
$\mathrm{C}_{\mathrm{NW}} \rightarrow \mathrm{W}_{\mathrm{NW}}$ (5 cases)

(d) Others (6 cases)

$\mathrm{W}_{\mathrm{SW}} \rightarrow \mathrm{W}_{\mathrm{SW}} ; \mathrm{W}_{\mathrm{SE}}+\mathrm{W}_{\mathrm{SW}} ; \mathrm{W}_{\mathrm{SW}}+\mathrm{C}_{\mathrm{NW}} ; \mathrm{W}_{\mathrm{NW}} \rightarrow$

$\mathrm{C}_{\mathrm{E}} ; \mathrm{C}_{\mathrm{NW}}+\mathrm{C}_{\mathrm{NE}} ; \mathrm{C}_{\mathrm{NE}}+\mathrm{C}_{\mathrm{NE}}$ (each 1 case)

The number of fronts involved in these relationships is 128 . Among them, 122 occurred between October and April and account for $44 \%$ of the total MFs during these seven 
months. The three-front combination of (a), (b) and (c) is found in ten cases. If we allow for weak MFs which have been omitted by our algorithm (Section 2.2), the number of combined fronts becomes still larger.

It can be seen from Figs. 9a and 20a that the $\mathrm{W}_{\mathrm{SE}}$ and $\mathrm{C}_{\mathrm{NW}}$ fronts typically occur in sequence during a temporal intrusion of warm air from the south coast. Thus the combination (a) is usually associated with the movement of a single MF. On the other hand, each of the combinations (b) and (c) involves two MFs, one in the southern Kanto plain and the other in the northern plain with a region of trapped cold air in between. It is interesting that the sequential relationship of $\mathrm{W}_{\mathrm{NW}} \rightarrow \mathrm{C}_{\mathrm{NW}}$ is rare (only one case) in (c). In fact, the time of the onset of the $\mathrm{W}_{\mathrm{NW}}$ front is later than that of the $\mathrm{C}_{\mathrm{NW}}$ front in 14 cases out of the 17 cases in (c). In other words, the warm air begins to retreat from the southern plain before being swept away by the strong northwest winds.

Fig. 26 shows an example of $\mathrm{W}_{\mathrm{Sw}}, \mathrm{C}_{\mathrm{Nw}}$ and $\mathrm{W}_{\mathrm{NW}}$ fronts on $30-31$ December 1985. As a cyclone passed the Sea of Japan, warm air spread over the southern Kanto plain accompanied by a $\mathrm{W}_{\mathrm{sw}}$ front, and went back in the form of a $\mathrm{C}_{\mathrm{NW}}$ front on the morning of 31 December (Fig. 26c). The northern part of the plain remained covered by cold air until a surge of strong northwest winds on the morning of 31 December. This was accompanied by a temperature rise, namely a passage of a $\mathrm{W}_{\mathrm{NW}}$ front. From 06 to 09 JST 31 December, the $\mathrm{C}_{\mathrm{NW}}$ and $\mathrm{W}_{\mathrm{NW}}$ fronts coexisted with the region of cold air trapped between them (Fig. 26b). The vertical section (Fig. 26d) indicates that this cold air was only about $100 \mathrm{~m}$ deep. At Mt. Tsukuba (not shown), the wind changed from southwest to northwest at around 09 JST 31 December with a temperature drop of $\sim 2^{\circ} \mathrm{C}$. This seems to correspond to the passage of the synopticscale cold front, but there was no other remarkable change in wind and temperature. Therefore the complicated behavior of MFs was essentially a boundary-layer feature related to the shallow cold air.

\section{Discussion}

\subsection{MWFs}

The MWF is characterized by shallow cold air corresponding to a localized airmass. Fujibe (1990b) statistically verified the presence of a cold-air pool in the inland region during a cyclone passage in the cold season. This explains the higher ratio of the number of MWFs to that of MCFs in comparison to other regions in middle latitudes, where cold fronts are a few times more frequent than warm fronts (e.g. Hoinka, 1985).

The structure of the $\mathrm{W}_{\mathrm{SE}} / \mathrm{W}_{\mathrm{SW}}$ front satisfies the definition of a coastal front, which is defined as a MF between maritime air and a colder airmass trapped inland (Nielsen, 1989). Fujibe (1990a) showed that the coastal front in the Kanto plain tends to move inland under strong onshore winds. This is nothing other than the $\mathrm{W}_{\mathrm{SE}} / \mathrm{W}_{\mathrm{Sw}}$ front described in this paper. Nielsen (1989) attributed the formation of coastal fronts to the land-sea differential heating and/or the orographic blocking of lowlevel air, while Bell and Bosart (1989) emphasized the activity of large-scale tropospheric disturbances during the generation of intense coastal fronts. In our analysis, the $\mathrm{W}_{\mathrm{SE}} / \mathrm{W}_{\mathrm{SW}}$ front occurs during the temperature rise at the $850 \mathrm{hPa}$ level, which implies the presence of the synoptic-scale frontal zone in a wide sense. Therefore both topography and large-scale baroclinicity are likely to contribute to the generation of a strong MWF.

It may be recommended to distinguish between MWFs associated with synoptic-scale fronts and those having a more localized character. By examining individual cases, we in fact find some MWFs coinciding with synoptic-scale warm fronts in surface weather maps, although many others occur well apart from synopticscale fronts. Even in the former cases, however, the MWFs are substantially sharper than a typical warm front in middle latitudes, suggesting the importance of topographic effects in sharpening a front locally. Moreover, the warming at the $850 \mathrm{hPa}$ level is observed in many cases of MWFs irrespective of the position of the synoptic-scale fronts. Thus it is 


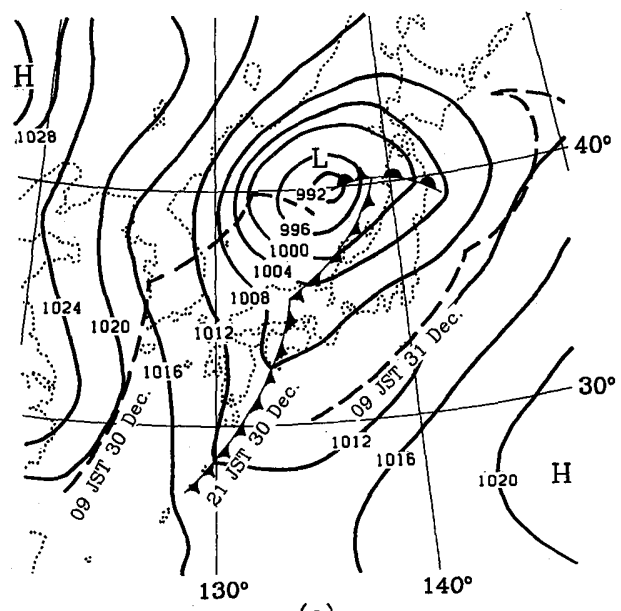

(a)

06 JST, 31 Dec. 1985

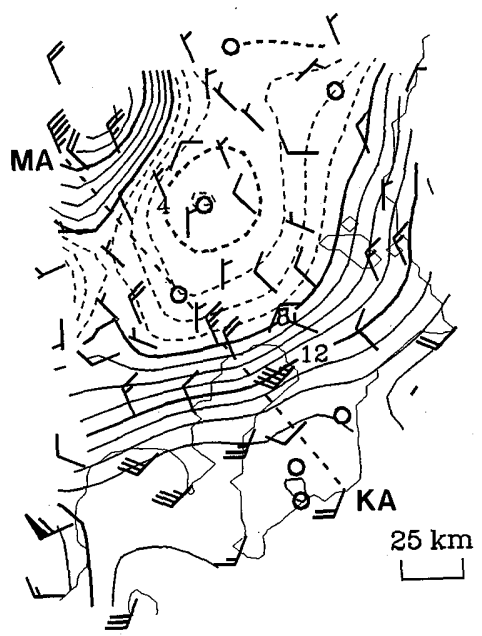

(b)
30-31 Dec. 1985

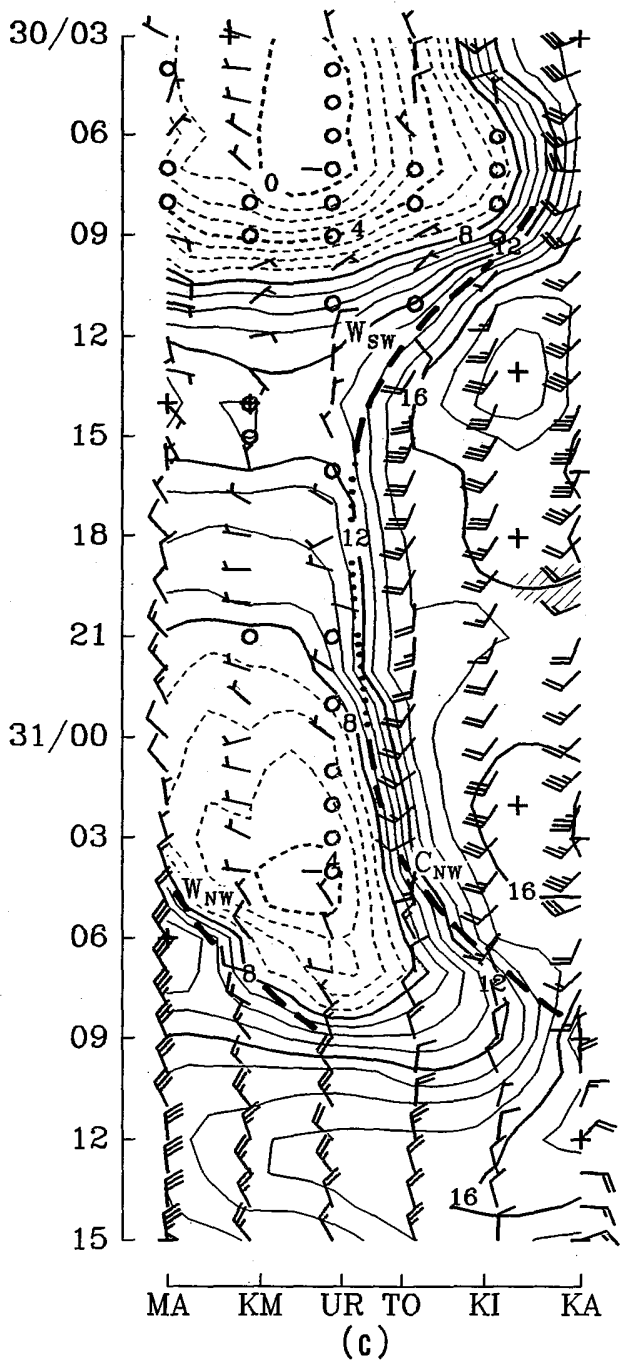

Fig. 26 (a) Surface weather map at 21 JST 30 December 1985 . The positions of the synoptic-scale front at 09 JST on 30 and 31 December are shown by dashed lines. (b) Surface wind and temperature at 06 JST 31 December. (c) Time section on the MA-KA line. (d) Vertical time section of wind and potential temperature at the MRI tower. 
not practical to classify these MFs into local fronts and synoptic-scale fronts, although there can be differences in the relative contributions of local and large-scale factors.

As for diurnal variation, Fujibe (1990a) showed that the coastal front in the non-rainy case tends to shift inland in the daytime. This corresponds to the maximum frequency. of MWFs in $06-12$ JST. There can be two ways in which daytime heating causes the front to move inland. In the first place, the warming of the cold-air pool will destroy the stable stratification which has prevented the strong low-level wind to reach the ground. In the second place, the warming over the land will increase the landward pressure gradient force. At present it is not certain which effect is the more important. Apart from the mechanism, the daytime inland movement of the $\mathrm{W}_{\mathrm{SE}} / \mathrm{W}_{\mathrm{sw}}$ front may be mistaken for a sea-breeze front unless the temperature field is carefully analyzed.

The $W_{\mathrm{NW}}$ front occurs in the field of a strong cold-air surge. The temperature rise is associated with the destruction of the surface cold-air pool and is confined within the lowest few hundred meters. A similar phenomenon is found in southern Germany when a cold-air pool is destroyed at the passage of a cold front (Hoinka et al., 1990). The frequent occurrence of the $\mathrm{W}_{\mathrm{NW}}$ front in the northern Kanto plain may be due to the adiabatic warming as the northwest wind blows down the Central Mountains, namely a foehn effect.

\subsection{MCFs}

The MCFs generally occur during the northwesterly cold-air surge in the synoptic field. However, the features of fronts differ considerably among the cases, especially according to seasons.

From late autumn to winter, the $\mathrm{C}_{\mathrm{Nw}}$ front typically corresponds to the retreating stage of the $\mathrm{W}_{\mathrm{SW}}$ or $\mathrm{W}_{\mathrm{SE}}$ front which has penetrated into the plain. On one hand the retreat coincides with the change in the synoptic-scale pressure field at the passage of a cold front, while on the other hand it is related to the diurnal cycle characterized by the development of the coldair pool in the nighttime. The cold air is very shallow $(100-200 \mathrm{~m})$ before the arrival of deep cold air (Figs. 20 and 26).

In comparison, the $\mathrm{C}_{\mathrm{NW}}$ front in spring and summer better fits the classical picture of the cold front with respect to the deep cold air at the leading edge and the precipitation in the postfrontal region (Figs. 18 and 20). This type of front is most frequent in the afternoon. This may be a general feature of cold fronts over the land, since Hoinka (1985) also showed that the cold frontal passage in southern Germany is about twice as frequent in the daytime (07-17 LST) as in the nighttime. A possible reason for the afternoon maximum is the unstable stratification of the daytime boundary layer, in which surface parameters are more sensitive to the transition in the free atmosphere than in the nocturnal boundary layer (Sturman et al., 1990). Another possible reason is the generation of convective precipitation which results in a sharp cold frontal head due to evaporative cooling. In fact, some MCFs in spring and summer are associated with heavy thunderstorms accompanied by strong gust fronts and/ or downbursts (e.g. Tabata et al., 1991).

In spring and summer, however, cold air arrives in the Kanto plain more often from the northeast or east than from the northwest. This may partly be attributable to the largescale environment in the warm season, in which cold air tends to arrive from the cold maritime region northeast of Honshu. However, Fig. 21 reveals that the easterly wind accompanying a $\mathrm{C}_{\mathrm{NW}} / \mathrm{C}_{\mathrm{E}}$ front is a local feature in the Kanto plain. It is likely that the Central Mountains block the shallow cold air arriving from the northwest and deflect it around their northern corner.

Northeasterly cold fronts are frequently observed in regions east of mountain ranges with shallow (1-2km) cold air as the common feature (Bosart et al., 1973; Colquhoun et al., 1985 ; Howells and Kuo, 1988 ; Sturman et al., 1990 ; Triet et al., 1990 : Chen and Hui, 1990 ; Smith et al., 1991). According to Bosart et al. (1973), the "back-door front" east of the Appalachians is mainly encountered in the warm season (most frequent in June) and often breaks the heat wave in the eastern states, but 
is rarely accompanied by heavy precipitation. This description applies to the $\mathrm{C}_{\mathrm{NE}} / \mathrm{C}_{\mathrm{E}}$ front quite well. The $\mathrm{C}_{\mathrm{NE}}$ front and the $\mathrm{C}_{\mathrm{E}}$ front have many common features, although the former tends to be more closely related to the synopticscale cold front, while the latter tends to have the character of a local front in the post-coldfrontal region. As seen from Fig. 25, the northwesterly foehn in the lee of the Central Mountains may contribute to the high temperature before the arrival of a $C_{E}$ front. This situation is like the case of the Colorado "upslope cold front" (Young and Johnson, 1984 ; Boatman and Reinking, 1984), which moves westward against the west wind in the lee of the Front Range of the Rockies.

The $\mathrm{C}_{\mathrm{NE}} / \mathrm{C}_{\mathrm{E}}$ front occurs predominantly in the afternoon under relatively fair weather associated with inland penetration of shallow, cool maritime air. In this respect it may look like a sea-breeze front. However, it has a number of features deviating from a typical sea-breeze front. In the first place, the easterly wind continues until midnight or even until the next day in some cases, resulting in a temperature fall on the synoptic time scale. In the case shown in Fig. 25, the daily maximum temperature at Tokyo was $19.6^{\circ} \mathrm{C}$ on 11 April, but it dropped to $9.0^{\circ} \mathrm{C}$ on 12 April. On the average for the $23 \mathrm{C}_{\mathrm{E}}$ fronts, the daily maximum temperature at Tokyo drops by $5.4^{\circ} \mathrm{C}$ the next day. In the second place, the easterly wind is often colder than the sea surface near the Kanto plain. According to the "Ten-day marine report" published by the JMA, the sea surface temperature along the east coast of the plain was $8-12^{\circ} \mathrm{C}$ in the first twenty days of April 1987. This was a few degrees higher than the air temperature after the midnight of 11 April, when the temperature was higher in the coastal region than in the inland region (Fig. $25 \mathrm{c}$ ). This indicates that the sea surface was a heat source, which is the situation just opposite to the sea breeze. It is also to be noted that some $C_{N E} / C_{E}$ fronts occur in the nighttime, although rarer than in the afternoon.

Therefore the $\mathrm{C}_{\mathrm{NE}} / \mathrm{C}_{\mathrm{E}}$ front should be regarded as associated with the intrusion of a large-scale cold airmass originating from a substantially high latitude, although the role of diurnal heating seems to be important as a trigger to the inland penetration of the cold air. Fujibe (1991) documented some remarkable examples of diurnal modulation on the movement of cold fronts. In one of his cases, a cold front displayed an oscillatory movement in central Honshu, resulting in repeated $\mathrm{C}_{\mathrm{NE}}$ frontal passages on the afternoons of the two successive days (3-4 September 1984). Physick (1988) made a numerical experiment on the effect of the daytime thermal contrast across a coastline in enhancing and accelerating a cold frontal system. Our analysis suggests the importance of a similar effect from a statistical viewpoint.

We find from these considerations that we have failed to detect typical sea-breeze fronts. This is because the sea-breeze front is weaker and more localized than is resolved by the hourly AMeDAS data. For example, Gamo (1991) showed that a sea-breeze front is rarely accompanied by a drop but only by a "leveling off" in the hourly time series of temperature. On the other hand, Ishikawa et al. (1986) detected many wind shift lines by using a dense anemometer network developed in the eastern Kanto plain, including sea-breeze fronts coming from the east coast. These appear to be MFs of smaller scales than is described in this paper, but we have little knowledge of the general features of MFs on this scale.

\section{Summary}

The features of the MWFs and MCFs described in this paper are summarized in Table 3. These MFs occur during the passage of synoptic-scale disturbances, and in this sense they are related to the large-scale frontal zone. However, they are more or less influenced by various mesoscale processes including

(1) the shallow cold-air pool in the field of warm-air advection,

(2) the northwesterly foehn in the lee of the Central Mountains,

(3) deflection of cold air around the northern corner of the Central Mountains, and

(4) diurnal heating and cooling of the land. 
Table 3

\begin{tabular}{|c|c|c|c|c|c|c|}
\hline Type & $\begin{array}{l}\text { Wind } \\
\text { direction }\end{array}$ & $\begin{array}{l}\text { Number of } \\
\text { cases }\end{array}$ & $\begin{array}{l}\text { Preferred } \\
\text { season }\end{array}$ & $\begin{array}{l}\text { Preferred } \\
\text { time of the day }\end{array}$ & $\begin{array}{l}\text { Typical depth } \\
\text { of the cold air }\end{array}$ & $\begin{array}{l}\text { Synoptic } \\
\text { condition }\end{array}$ \\
\hline $\mathrm{W}_{\mathrm{SE}}$ & $90-180^{\circ}$ & 20 & Spring and autumn & $(06-12 \mathrm{JST})$ & $\begin{array}{l}\text { A few hundred } \\
\text { meters }\end{array}$ & $\begin{array}{l}\text { East of a } \\
\text { cyclone }\end{array}$ \\
\hline $\mathrm{W}_{\mathrm{sw}}$ & $180-240^{\circ}$ & 114 & Autumn-spring & 06-12 JST & $\begin{array}{l}\text { A few hundred } \\
\text { meters }\end{array}$ & Warm sector \\
\hline $\mathrm{W}_{\mathrm{NW}}$ & $270-360^{\circ}$ & 56 & Winter & 06-12 JST & $\begin{array}{l}\text { A few hưndred } \\
\text { meters }\end{array}$ & $\begin{array}{l}\text { Cold-air } \\
\text { outbreak }\end{array}$ \\
\hline $\mathrm{C}_{\mathrm{NW}}$ & $255^{-} 15^{\circ}$ & 97 & Autumn-spring & $\$$ & $\begin{array}{l}\text { A few } \\
\text { kilometers \# }\end{array}$ & $\begin{array}{l}\text { Cold-air } \\
\text { outbreak }\end{array}$ \\
\hline $\mathrm{C}_{\mathrm{NE}}$ & $15^{-} 75^{\circ}$ & 53 & Spring-summer & 12-18 JST & $\sim 1 \mathrm{~km}$ & $\begin{array}{l}\text { Weak cold-air } \\
\text { outbreak }\end{array}$ \\
\hline $\mathrm{C}_{\mathrm{E}}$ & $75-135^{\circ}$ & 24 & Spring-summer & 12-18 JST & $\sim 1 \mathrm{~km}$ & $\begin{array}{l}\text { Weak cold-air } \\
\text { outbreak }\end{array}$ \\
\hline
\end{tabular}

$\$$ Nighttime in late autumn-winter; 12-18 JST in spring-summer.

\# In late autumn-winter, a few hundred meters at the leading edge.

These processes are typically related to the features of

(1) the three types of MWFs and part of the $\mathrm{C}_{\mathrm{Nw}}$ front,

(2) the $\mathrm{W}_{\mathrm{NW}}$ front and the prefrontal condition of the $\mathrm{C}_{\mathrm{E}}$ front,

(3) the $C_{N E}$ and the $C_{E}$ front, and

(4) all types of fronts,

respectively. Naturally these are only the rough outlines of MFs which involve all kinds of variabilities among the cases.

Acknowledgments :- - Surface data were obtainde from the data files in the charge of the Computer Room of the MRI. Computation was made by using the HITACM-280D computer of the MRI.

\section{References}

Akima, H., 1970: A new method of interpolation and smooth curve fitting based on local procedures. J. Assoc. Comp. Mach., 17, 589-602.

Bell, G. D. and L. F. Bosart, 1989: The large-scale atmospheric structure accompanying New England coastal frontogenesis and associated North American east coast cyclogenesis. Q.J. R. Meteorol. Soc., 115, 1133-1146.

Boatman, J. F. and R. F. Reinking, 1984 : Synoptic and mesoscale circulations and precipitation mechanisms in shallow upslope storms over the western high plains. Mon. Weather Rev., 112, 1725-1744.

Bond, N. A. and R. G. Fleagle, 1985 : Structure of a cold front over the ocean. Q.J. R. Meteorol. Soc., 111, 739-759.

Bosart, L. F., 1975 : New England coastal frontogenesis. Q. J. R. Meteorol. Soc., 101, 957-978.

Bosart, L. F., V. Pagnotti and B. Lettau, 1973: Climatological aspects of eastern United States back-door frontal passages. Mon. Weather Rev., 101, 627-635.

Chen, Y.-L. and N. B.-F. Hui, 1990 : Analysis of a shallow front during the Taiwan Area Mesoscale Experiment. Mon. Weather Rev., 118, 2649-2667.

Colquhoun, J. R., D. J. Shepherd, C. E. Coulman, R. K. Smith and K. McInnes, 1985: The southerly burster of south eastern Australia: an orographically forced cold front. Mon. Weather Rev., 113, 2090-2107.

Fujibe, F., 1990a : Climatology of the coastal front in the Kanto plain. Pap. Meteorol. Geophys., 41, 105-128.

Fujibe, F., 1990b: Surface wind systems and cold airmasses in central Honshu during short-term precipitation events. Tenki, 37, 835-843 (in Japanese).

Fujibe, F., 1991: Diurnal modulation of the movement of surface cold fronts in central Honshu: Examples in the warm season. J. Meteorol. Soc. Japan, 69, 439-448.

Fujibe, F. and T. Asai, 1984: A detailed analysis of the land and sea breeze in the Sagami Bay area 
in summer. J. Meteorol. Soc. Japan, 62, 534-551.

Gamo, M., 1991 : Comparison of methods determining the location of the sea-breeze front. Kogai (Pollut. Control), 26, 31-39 (in Japanese with English abstract).

Garratt, J. R., P. A. C. Howells and E. Kowalczyk, 1989: The behavior of dry cold fronts traveling along a coastline. Mon. Weather Rev., 117, 1208-1220.

Hartjenstein, G. and J. Egger, 1990 : Frontogenesis near steep orography. Tellus, 42A, 259-269.

Hoinka, K. P. 1985 ; On fronts in central Europe. Contrib. Atm. Phys., 58, 560-571.

Hoinka, K. P., M. Hagen, H. Volkert and D. Heimann, 1990; On the influence of the Alps on a cold front. Tellus, 42A, 140-164.

Hoskins, B. J. and F. P. Bretherton, 1972: Atmospheric frontogensis models: Mathematical formulation and solution. J. Atm. Sci., 29, 11 -37 .

Howells, P. A. C. and Y.-H. Kuo, 1988: A numerical study of the mesoscale environment of a southerly buster event. Mon. Weather Rev., 116, 1771-1788.

Ishikawa, T., M. Tanaka, S. Yamazaki and H. Suzuki, 1986: Studies on the structure and dynamics of sea-breeze fronts. Proc. Japan Soc. Civ. Eng., No. 375, 261-270 (in Japanese with English abstract).

Kawamura, T., 1977 : Areal distribution of surface winds in Japan. Tech. Rep. JMA, No. 91, 76pp. (in Japanese with English abstract).

Kimura, F., 1985: A numerical simulation of local winds and photochemical air pollution (II): Application to the Kanto plain. J. Meteorol. Soc. Japan, 63, 923-936.

Kondo, H., 1990: A numerical experiment of the "extended sea breeze" over the Kanto Plain. $J$. Meteorol. Soc. Japan, 68, 419-434.

Nakane, H. and Y. Sasano, 1986: Structure of a sea-breeze front revealed by scanning lidar observation. J. Meteorol. Soc. Japan, 64, 787 $-792$.

Nielsen, J. W., 1989: The formation of New England coastal fronts. Mon. Weather Rev., 117, 1380-1401.

Nielsen, J. W. and P. P. Neilley, 1990 ; The vertical structure of New England coastal fronts. Mon. Weather Rev., 118, 1793-1807.

Nomoto, S., 1975 : A synoptic climatological analy- sis on local anticyclones, cyclones and fronts in Central Japan. Geogr. Rev. Japan, 48, 424-437 (in Japanese with English abstract).

Ogura, Y. and D. Portis, 1982 : Structure of the cold front observed in SESAME-AVE III and its comparison with the Hoskins-Bretherton frontogenesis model. J. Atm. Sci, 39, 27732792.

Physick, W. L., 1988: Mesoscale modeling ot a coru front and its interaction with a diurnally heated land mass. J. Atm. Sci., 45, 3169-3187.

Sakakibara, H., 1983: Meso- and small-scale structures of a cold-frontal precipitation system affected by a small low and mesoscale orography. Pap. Meteorol. Geophys., 34, 61-73.

Shapiro, M. A., 1984: Meteorological tower measurements of a surface cold front. Mon. Weather Rev., 112, 1634-1639.

Smith, R. K., R. N. Ridley, M. A. Page, J. T. Steiner and A. P. Sturman, 1991 : Southerly changes on the east coast of New Zealand. Mon. Weather Rev., 119, 1259-1282.

Sturman, A. P., R. K. Smith, M. A. Page, R. N. Ridley and J. T. Steiner, 1990: Meso-scale surface wind changes associated with the passage of cold fronts along the eastern side of the Southern Alps, New Zealand. Meteorol. Atm. Phys., 42, 133-143.

Sugiura, S., 1974 : Small scale analysis of cold front passing Kanto district. Tenki, 21, 39-45 (in Japanese).

Tabata, A., K. Akaeda, M. Ishihara and H. Sakakibara, 1991: Structure of downbursts associated with heavy rainfall observed in Tokyo. Preprint of the 25th conference on radar meteorology, AMS, J77-J80.

Trier, S. B., D. B. Parsons and T. J. Matejka, 1990 : Observations of a subtropical cold front in a region of complex terrain. Mon. Weather Rev., 118, 2449-2470.

Yamamoto, A., 1984: Meso-scale analysis in a front passing through the central Japan in spring. Kenkyu-jiho (J. Meteorol. Res.), 36, 1-14 (in Japanese).

Yoshino, M. M., 1975: Climate in a small area. University of the Tokyo Press, 549pp.

Young, G. S. and R. H. Johnson, 1984 : Meso- and microscale features of a Colorado cold front. $J$. Clim. Appl. Meteorol., 23, 1315-1325. 


\section{関東平野に現れるメソ温暖・寒冷前線の気候学}

\section{藤部文昭}

11 年間のアメダス資料を使って, 関東平野に現れるメソ温暖前線とメソ寒冷前線の統計的な調査をした。ここ で言うメソ前線とは幅 $20 \sim 30 \mathrm{~km}$ 以下の気温・風の急変線のことであり，その基準としては， 1 時間に $1.5^{\circ} \mathrm{C}$ 以 上の気温変化を伴う風向・風速の変化が 8 地点以上に現れることを条件とした。この条件を満たす 190 例のメソ 温暖前線と 177 例のメソ寒冷前線を対象として, 発現頻度や形態の季節変化・日変化, 総観場との対応関係を調 ベた。

メソ温喛前線は低気圧前面の南東風，暖域の南西風あるいは寒気吹き出し時の北西風に伴って現れ，これらが 平野部に存在する薄い (数百 $\mathrm{m}$ 以下) 冷気層を侵食していく形態をとる。南東風前線は主に春の温帯低気圧と秋 の台風の時に現れ, 降水を伴うことが多い。南西風前線は 1 年を通じて現れるが秋〜春に多く, 秋〜冬は主に南 関東に, 春〜夏は北関東に現れる。北西風前線は $12 \sim 3$ 月に多く, 平野北西部から強い北西風が吹き出してくる 時に現れる。降水がある場合を除き，メソ温暖前線は 6 ～12 時に最も頻度が高い。

メソ寒冷前線は一般に寒気吹き出し時に現れるが, 北西風以外に北東〜東風に伴うものもある。北西風前線は 厚い $(\sim 2 \mathrm{~km})$ 寒気を伴っているが, 晚秋〜冬にはメソ温暖前線として北上してきたものが寒冷前線となって南 下していくことが多く, (1) 先端部では寒気がごく薄い $(200 \mathrm{~m}),(2)$ 夜に多い, という特徴がある。一方, 春 〜夏の北西風前線は午後に現れる傾向がある。しかし, 春〜夏にはむしろ北東〜東風前線が平野北東部から侵入 してくることが多く，これら (特に東風前線) は (1) 総観規模前線の通過から数時間〜半日程度遅れて現れる，(2) 寒気の厚さは $1 \mathrm{~km}$ 程度で，しばしば下層雲伴う，(3) 午後に侵入することが圧倒的に多い，などの特徴を持って いる。

これらのメソ前線は低気圧通過前後の暖気・寒気侵入に付随して現れるもので，この意味では前線帯内の現象 であるが, 天気図に描かれた前線と $1: 1$ に対応するとは限らず,一般的には基本場の傾圧性と地形効果との複合 によってできると考えられる。 